\title{
Using Recycled Photovoltic Modules and Batteries for Engineering Educa- tion, Student Projects, and as Viable Portable, Backup Storage Power Sources
}

\section{Dr. Robert W. Fletcher, Lawrence Technological University}

Robert Fletcher joined the faculty of the Mechanical Engineering Department at Lawrence Technological University in the summer of 2003, after two decades of various industry engineering positions in research, and product development.

Dr. Fletcher earned his Bachelor of Science Degree in Chemical Engineering from the University of Washington, in Seattle, and the Master of Science and Ph.D. degrees in Chemical Engineering, both from the University of Michigan.

He teaches a number of alternative energy courses at Lawrence Tech. Dr. Fletcher and his student research team is focusing on energy usage and efficiencies of several traditional and alternative energy systems.

\section{Naim R. Shandi, Lawrence Technological University}

Undergraduate student in Electrical Engineering at Lawrence Technological University. 


\title{
Using Recycled Photovoltic Modules and Batteries for Engineering Education, Student Projects, and as Viable Portable, Backup Storage Power Sources
}

\begin{abstract}
:
As the efficiencies of new photovoltaic (PV) modules continue to increase, and their purchase prices dramatically decrease, companies and organizations that were early adopters of PV energy sources are now often upgrading their sometimes decades-old PV arrays to the newer, higher efficiency PV systems. The installation of these upgraded PV systems often, unfortunately, result in the older and fully depreciated, but still reasonably functional, PV modules being hastily disassembled (sometimes destructively), scraped and sent to a landfill. Recently, the Alternative Energy Engineering program at Lawrence Technological University (LTU) received donated, scrapped, and older Isofoton I-94/24 PV modules from Masco Corporation, a local industrial partner of the LTU College of Engineering. In this paper, the faculty and student authors show how these scrapped, but still functional, PV modules can yet have a useful life. The initial performance assessment of each module by the authors using a simple, low-coast variable resistance testing set-up to sort-out working and non-working modules is discussed. Examples of the generated module performance test data are presented. Also reviewed are how these test data, along with Isofoton product literature, were used in the circuit design for their integration with recycled 12-volt lead-acid batteries (available from a previous university project) into a portable, and expandable, back-up, photovoltaic power-source student project. Also, a possible approach for how this integrated system could serve as a prototype for how such recycled modules and batteries might be used for viable energy storage systems in the future is proposed. Lastly, student feedback regarding their experience, knowledge gained, and the benefits they received in participating in this project are documented.
\end{abstract}

\section{Introduction:}

Lawrence Technological University (LTU or Lawrence Tech) has offered an alternative energy engineering program since 2003, and has been documented previously [1]. The faculty-author of this paper is the director of that program, and has been since its inception. Due to the high level of student interest, there is always an on-going desire to find appropriate renewable energy projects for students to take on and to participate in for the program. Lawrence Tech also faces the challenge common to all universities of securing funding for such student projects, and making available the faculty time needed to properly supervise and support those projects. High value engineering projects, at low-cost are very desirable. Often corporate donations of equipment and materials help, and using those materials does provide valuable opportunities for students to learn and participate in truly meaningful educational activities. These are the origins of this project.

The unique and interesting aspect of this faculty-student project focuses on how it is indeed possible to use older, recycled photovoltaic modules (donated to Lawrence Tech from a partnering company in Southeast Michigan) and several deep-discharge, 12-volt, lead-acid batteries that were available and used on a previous project at Lawrence Tech in 2007, and integrate these into a viable power system. This on-going project is a portable PV powered 
prototype system with energy storage and various energy outputs. We have now physically demonstrated this integrated system's ability to capture solar energy and convert it to DC power, to deliver 110 volts AC, and both 24 volt DC and 12 volt DC output power in both laboratory and out-door experimental setups. Another important aspect of this project is that the PV power source is expandable. The basic stand-alone cart has two PV modules (at approximately 100watts each), but the design also allows for an additional four more PV modules (yielding to up to $\sim 600$ watts total) providing greater solar source power for quicker battery charging, or more daytime external power delivery. The system is also expandable to incorporate additional battery storage.

\section{Background:}

The goal of this on-going project is to design and build a self-contained and portable photovoltaic (PV) power system with on-board electric energy storage batteries using repurposed and recycled materials.

The 12 volt, lead-acid deep-discharge batteries used in this project were "left-over" batteries from the Solar Decathlon competition in which Lawrence Tech entered and competed in 2007. The Solar Decathlon, sponsored by the US Department of Energy, at that time was an international collegiate competition where students were challenged to build a full-scale, energyefficient, livable home powered only by renewable energy technologies. The Lawrence Tech design incorporated a photovoltaic power system with several deep discharge, lead-acid batteries. Four batteries "left-over" from that system where kept in the school's alternative and renewable energy laboratory by the faculty-author of this paper. These batteries are eleven years old, but had seen only minimum use over that time. To prevent shelf-life aging these batteries were lightly discharged and recharged approximately once every six months to help keep them viable. No exact record was kept, but the six months was generally the cycling time frame. Typically, this involved partially discharging the batteries for 4 to 5 minutes using a 6 ohm power resistor. Then the batteries were recharged using a standard automotive battery charger until the charger turned off per its internal controls. The batteries were returned and stored to the cool, dry location in the LTU alternative energy lab.

In the summer of 2013, MASCO Corp. donated twelve Isofoton I-94/24 PV modules to Lawrence Tech, along with a $1.0 \mathrm{~kW}$ solar water heating system. MASCO Corporation. corporate headquarters are located only a few miles from Lawrence Tech, in Southeast Michigan. Their business focus is the design, manufacture and distribution of numerous wellknown home improvement and building products [2]. MASCO is one of several corporate partners with Lawrence Tech and employs several of LTU's engineering graduates. In the mid2000's MASCO Corp. was evaluating various renewable energy systems and assessing how they could be integrated into some of their product lines. They had several renewable energy development projects underway involving solar water heating and solar photovoltaics. Upon the completion of these development projects MASCO decommissioned the projects and placed the related hardware into long-term storage in 2010. It was these solar heating and PV systems that were donated to Lawrence Tech, and these PV modules that are being used in this project. 
The reuse of these PV modules points to a much larger opportunity for potential low-cost and non-critical photovoltaic projects. Early adopters of PV technology from 10 to 15 years ago, or longer, are starting to upgrade their PV power arrays, as these older systems are now fully cost depreciated. As a result, large quantities of used, but still functional PV modules are becoming available. These used, older modules, typically do have some level of age-degradation and usually do not have the high performance of the newer and more efficient PV technologies. Depending on the PV technology (amorphous silicon, crystalline or polycrystalline, or some other photosensitive material), various levels of age and solar exposure will result in performance degradation. These performance degradations are well documented [6][7][8]. In most cased these decommissioned modules are, however, fully-functional and can still have a useful life. Their low cost (and in some cased "no cost", being they are fully depreciated and can be donated, as was the case with the Lawrence Tech modules used in this project) make them still-viable power sources for non-critical, and useful applications. It is estimated that the Isofoton I-94/24 PV modules used in this system have encountered a $V_{o c}$ degradation of approximately $4.5 \%$ and an $I_{s c}$ degradation of approximately $14.2 \%$ (see Appendix C and reference 20 and 21 for sample calculations).

Our repurposed and reuse approach is different than what is often discussed in recycling and Life-Cycle- Analysis, where a given technology is reprocessed and its composite materials are returned to their raw or base form. This more fundamental recycling has been discussed extensively in the literature [9]. This new re-use of PV modules is starting to gain interest, however, and is now considered a viable option for some PV applications, including engineering education [10].

The authors believe this project is fundamentally important because, if successful, it can serve as a demonstration of low-cost, and reliable photovoltaic applications. Utilization of these previously used photovoltaic modules can provide engineering schools with constrained and limited budgets the opportunity to obtain functional PV modules, and in some cases fully operating systems. This can render these systems available to students for general testing, study, and variety of unique projects. Another aspect of this project is that it may be possible to demonstrate the viability of applications in low-income areas, or in remote, rural communities that face limited electric power availability, and may have financial constraints which limit their access to energy storage and photovoltaic systems [11] [12].

So what is a possible approach that interested university faculty can use to get access to these decommissioned PV modules, and system components? It must be understood that very often the decommissioning of PV systems is often done by PV installers. They are requested to take way the old system and install a new, higher efficiency system. We recommend that interested faculty directly contact their local PV installers and ask about the availability of older modules. Inquire if it is possible to come and pick up discarded modules or PV hardware at the job site. Offer to remove all functional materials at no cost to the installer. Such an approach might provide several opportunities to obtain working modules, hardware or even complete systems. 


\section{Individual Photovoltaic Module Testing and Characterization:}

As mentioned, Isofoton I-94/24 PV modules were used in this project (see Appendix A for manufacture details regarding these modules) from a decommissioned system operated by Masco Corp. Prior to donation to Lawrence Tech in the summer of 2013, the twelve PV modules were stored outside for what is believed to have been three years (the exact time is not known). During this outdoor storage the modules were stacked one-on-top of another face-down, and unfortunately were not covered. They were subject to snow and ice buildup on the rear-side framing, and several freeze-thaw events over their outdoor storage period. Because of this, major physical damage was observed by LTU on two modules, rendering them unusable. These where, therefore, set aside for classroom show-and-tell educational purposes only.

Before any consideration of which remaining ten modules could be used, it was necessary to characterize their power output for stability, safety, and uniformity. Rudimentary current/voltage plots (i-V curves) and power characterizations where carried out individually on each module using a simple variable resistance circuit in direct sunlight during the summer of 2018 to assure the modules were fully functional and not damaged. Solar insolation (also known as irradiance, or power density) during these characterizations were typically between $750 \mathrm{~W} / \mathrm{m}^{2}$ and 850 $\mathrm{W} / \mathrm{m}^{2}$. All insolation readings were measured with a LI-COR LI-250A light meter. Short circuit currents $\left(I_{s c}\right)$ were typically between 2.25 and $2.75 \mathrm{amps}$, and open-circuit $\left(V_{o c}\right)$ were typically 31 to 35 volts, depending on solar insolation and air temperature. Ambient and module surface temperatures were measured during each characterization test using K-type thermocouples taped to the back of each module tested as well as the open ambient air in a shaded area next to the modules. For quick setup all electrical connections were made using simple laboratory alligatorclip leads.

Data acquisition was accomplished using a Graphtec GL-240; Compact Standalone 10-Channel Datalogger. Currents were measured using $10 \mathrm{amp} / 10 \mathrm{mV}$ current shunts (Crompton), and an Electronics-Salon 100 watt $50 \mathrm{ohm}$, high power, wire-wound, variable resistor. An example of the electrical schematic is shown in Figure 1 below.

Figure 2(A) below shows the basic outdoor test stand for evaluating each individual module. A separate lab cart (not part of this project system design) was used to transport and hold the materials required for data collection.

Today all commercially available PV modules have bypass diodes internally installed for safety protection to prevent reverse current flow during cell shading. The need for bypass diodes in PV modules, and PV arrays is well known, well understood, and well documented [13] [14] [15]. It is vital that any used or recycled modules be checked to assure these bypass diodes are fully functional. It is possible to do a quick (but not always effective) check of PV diodes using a common lab multi-meter with a standard diode check setting. This, however, may not be adequate because $\mathrm{PV}$ modules often operate at $30^{\circ} \mathrm{C}$ to $50^{\circ} \mathrm{C}$ above ambient temperatures. Warm diodes may perform differently at elevated temperatures than at room temperature. Therefore, checking diodes at elevated temperatures during solar exposure is critical [16] [17]. This was done by simply affixing a series of cardboard strips over various individual cells on each module 
and conducting a standard IV sweep. Figure 2(B) shows the testing set-up for how these diodes were evaluated for each module.

The authors were plesantly surprised to find good performance between all ten photovoltaic modules when characterized in outdoor sun testing. Figures 3 shows a typical i-V plot for one of the properly functioning Isofoton modules. Figure 4 shows the i-V sweep plot for the module with cardboard strips over various cells to assess the bypass diodes.

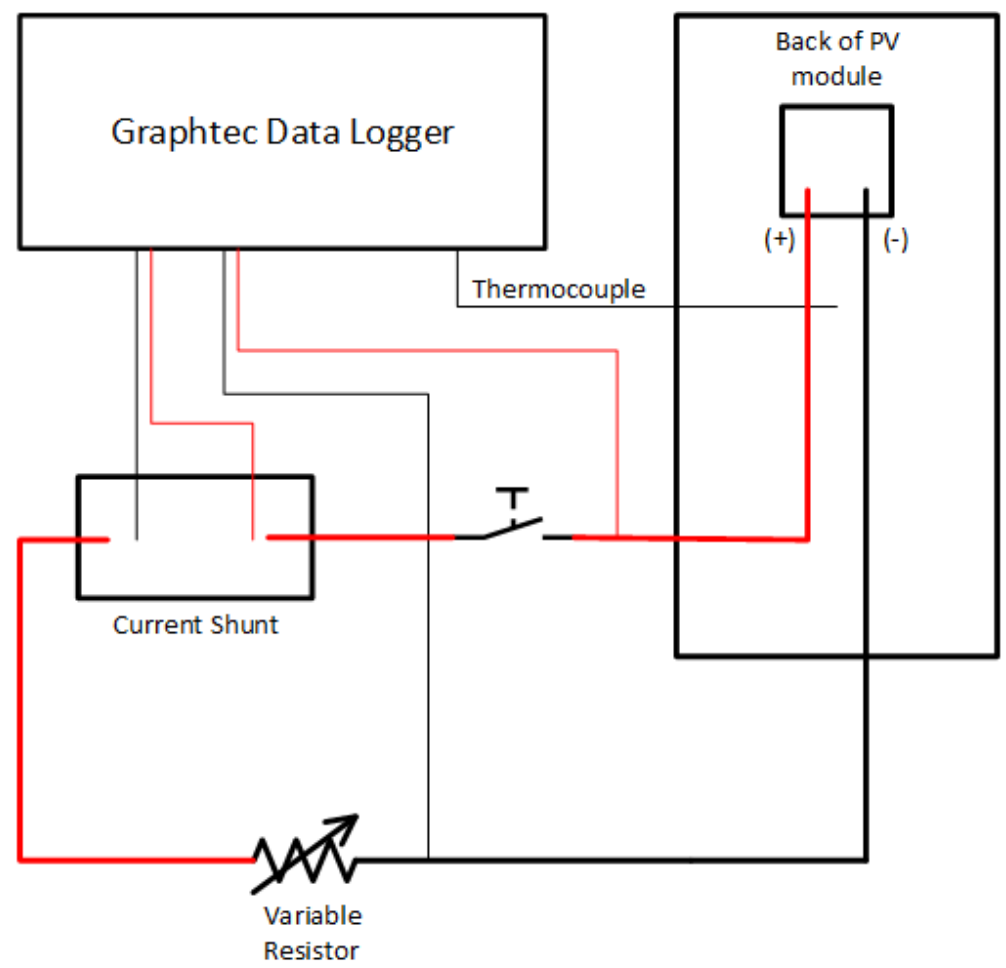

Figure 1: The basic circuit schematic for characterization testing of each PV module.

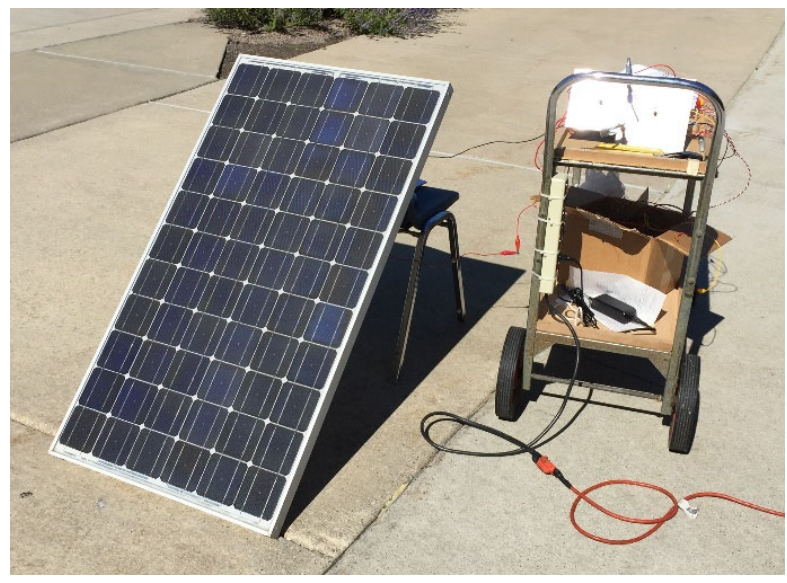

(A)

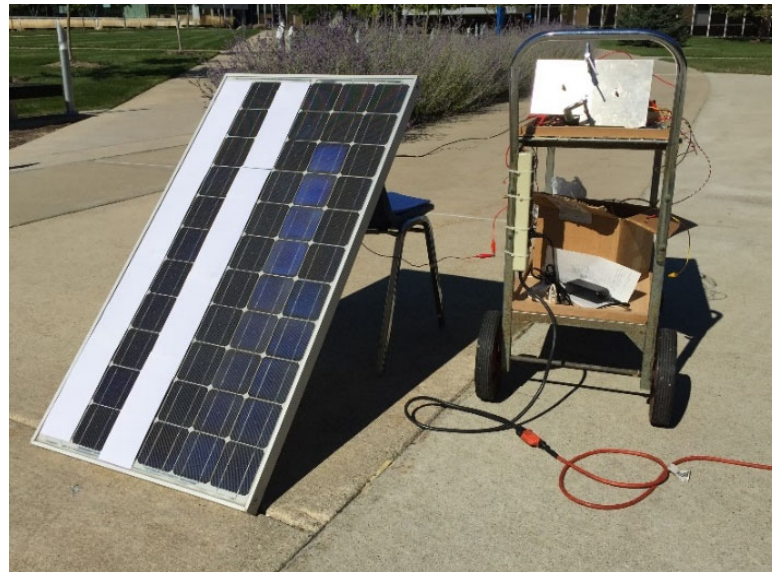

(B)

Figure 2: Shown here are the basic outdoor testing condifuration of the Isofoton I-94/24 PV modules. the basic test stand setup is shown in (A). The assessment of module bipass safety diodes is illustrated in (B) showing carboard strips shading various cells. 


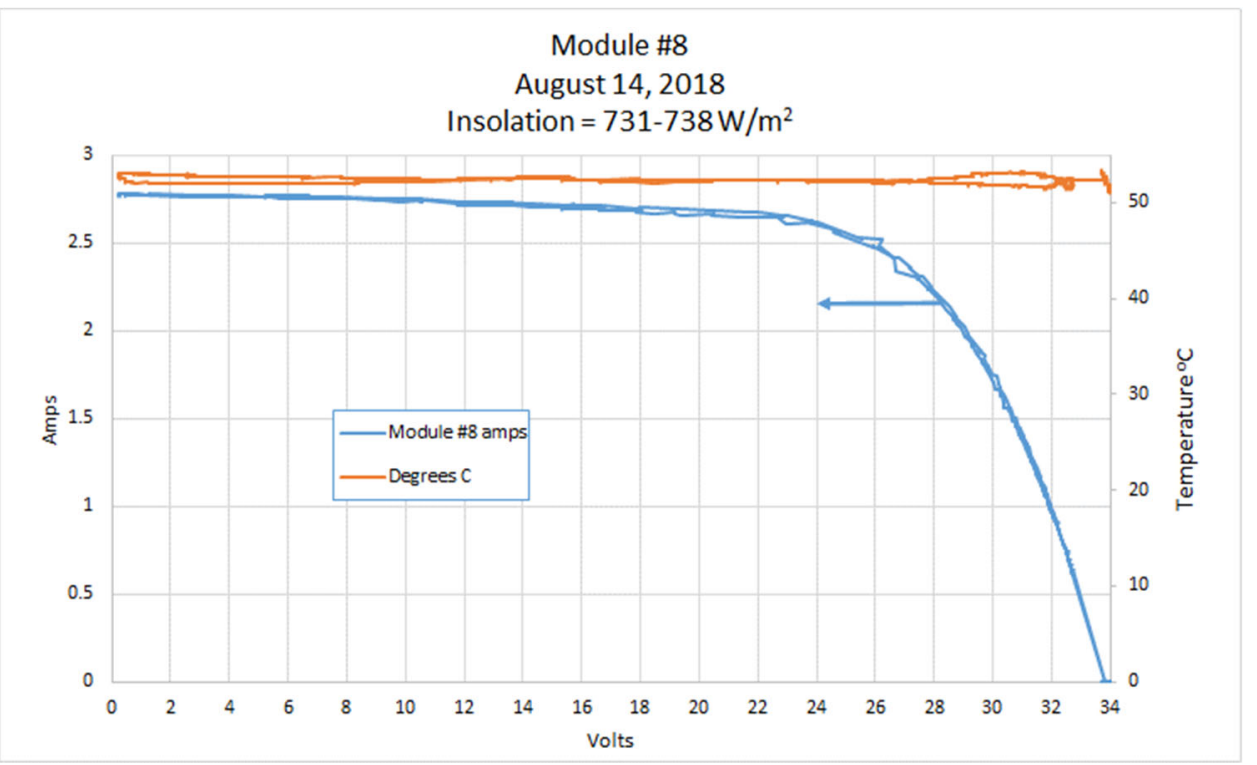

Figures 3: Shown here is a typical i-V plot for one of the test modules. Excellent uniformity was observed between all of the modules characterized.

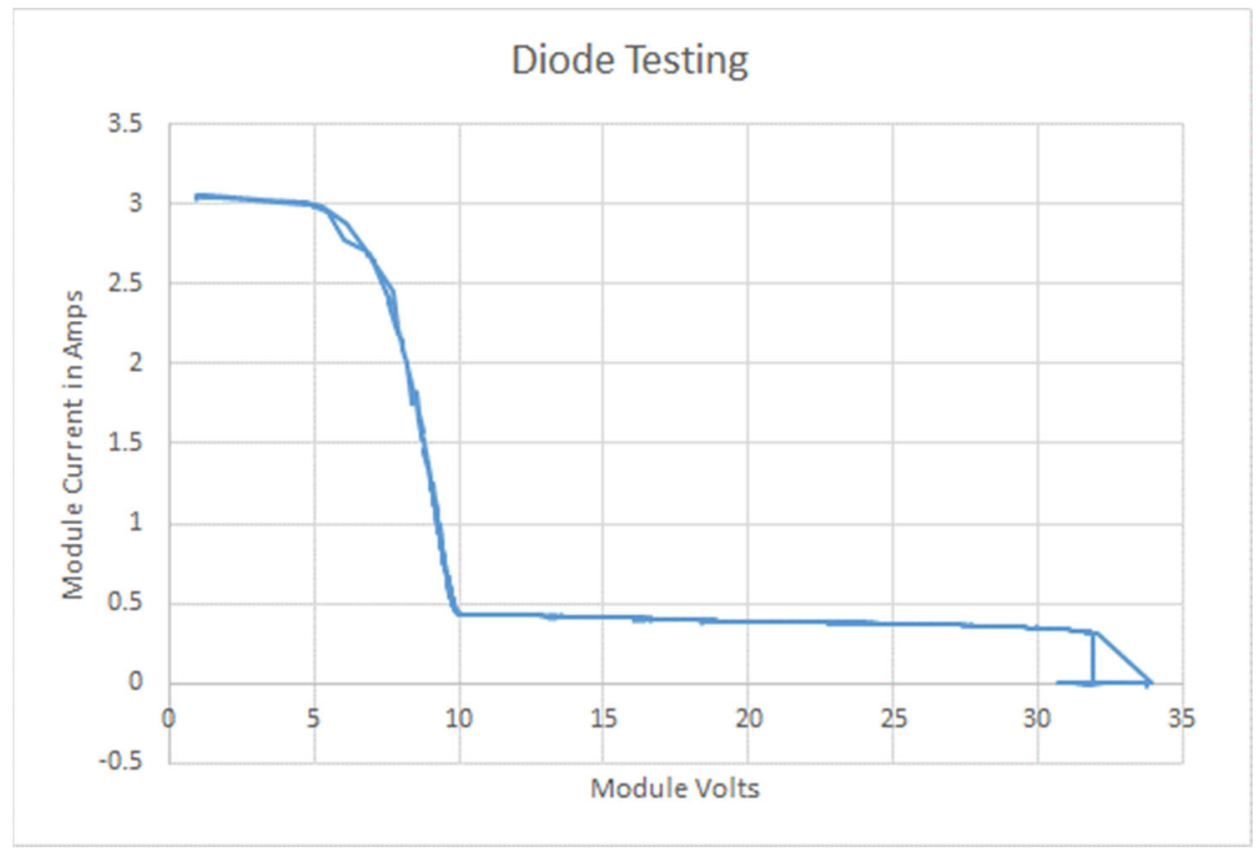

Figure 4: The i-V plot for the module illustrated above in Figure 2(B) above, with cardboard strips shading strings of cells in the module to assess the bypass diodes. This characteristic plot indicates correct bypass diode operation.

\section{Battery Testing and Verification:}

The deep-discharge batteries used in this study are Discover EV24-80 amp-hour lead acid batteries. (Note: these have now been re-designated by the manufacturer as 85 amp-hour batteries. Specifications for the original 80 Amp-hour batteries are no longer available from the manufacturer. But specifications for the $85 \mathrm{amp}$-hour batteries are available and are posted in 
Appendix B.) As mentioned previously, the batteries were stored in a cool, dry location in the Lawrence Tech renewable energy lab for approximately eleven years, but had been occasionally discharged and recharged with the intent to help maintain their functionality. Even when this is done there is a natural degradation of lead-acid batteries. The rule of thumb for such batteries is to charge them every few months. But after five to six years of storage along with infrequent use, it is not uncommon for lead acid batteries to become chemically inactive displaying limited, charging and discharging. Such batteries may not recover.

Initially, as would be expected, these batteries showed low electrochemical activity after their prolonged storage. There are, however, various documented methods for how to maintain and revitalize lead-acid batteries [3] [4] [5]. At the start of this project in the early summer of 2018 variations of these methods were used to "bring back from the dead" these Discovery lead acid batteries required for this project. We at LTU have found marginally, or seemingly dead 12-volt lead-acid batteries can often be revitalized back to some level of electrochemical activity. There is no single set protocol for guaranteed success. The protocol provided here may not revive a dead battery, but generally the Lawrence Tech process is as follows:

1) Using a high internal resistance multi-meter determine if the lead-acid battery has any residual voltage, if not, then it may not be a successful candidate for this process.

2) Using a DC power supply, bring the input voltage up to 15 to 18 volts for 2 to 4 minutes (note that voltages in this range can result in electrolysis of the battery electrolyte, so this should not be done over prolonged periods of time and must not be left un-attended) and then turn off the voltage for a similar amount of time.

3) Check to see if any increase in voltage is observed.

4) Repeat steps 2 and 3 for four to six times.

5) If an increase in voltage is observed, then using the DC power supply apply 15 volts for 10 to 15 minutes and disconnect.

6) Check the voltage for a possible voltage increase.

7) Using a power resistor ( 5 to $10 \mathrm{ohms}$ ), discharge the battery for a few minutes to approximately 11.5 volts.

8) Repeat steps 5, 6, and 7 four to five times or more if electrochemical activity is observed.

9) Using a standard automotive battery charger (see below), charge the battery until the charger automatically turns off.

10) After charging, discharge the battery to approximately 11.5 volts, and do this charge and discharge activity several times, to determine if the capacity of the battery is increasing. Such repeated light-duty cycling can often help a battery recover to some nominal level of functionality.

The current retail price for similar new batteries is approximately $\$ 240$ each! Obviously, it was highly desirable to recover these batteries, if at all possible, due to their high cost. Most recharging of these batteries was done using a standard automobile battery charger (Schumacker SC-600A Automatic SpeedCharge battery charger), however, some charging was also done using an available laboratory variable-voltage/current power supply. A typical charging profile for one of the Discovery EV24-80 amp-hr batteries is shown in Figure 5 below. 
After several attempts using the above prescribed recovery methods success was obtained with these four batteries. The test data, however, did show that degradation had taken place with these batteries. A quick (and an admittedly rough) calculation using the assumption of an average discharge of 12 volts and the rated $80 \mathrm{amp}-\mathrm{hrs}$ yields a value of $960 \mathrm{~W}$-hr. Since 1 hour equals 3600 seconds an estimate of 3.5 MJ in each battery can be made for a complete and total discharge of each battery (if they were new units). However, total discharge is highly undesirable, even for deep-discharge batteries, and a not-to-exceed maximum discharge of 50\% was selected (and is more typically used as a discharge level to assure longer battery cycle life). Thus, a usable capacity of 1.7 MJ per new battery is a better estimate of available energy. Figure 6 below shows discharge results for two of the batteries in series ( 24 volts nominal). The various wattage discharges in this series of tests were accomplished at constant watts over the duration of each discharge test using a Morningstar ProStar PS-MPPT-25M; 25 amp 12/24 volt MPPT charge controller. (This charge controller will be used in the final configuration of the portable power cart design.) High discharge rates typically result in lower estimates of available energy, and low discharge rates provide a more accurate estimate of real available energy level in batteries. Preventing excessive battery discharge is typically accomplished by preventing batteries from discharges below 11.5 volts. This is how the Morningstar charge controller, used for these tests, functions.

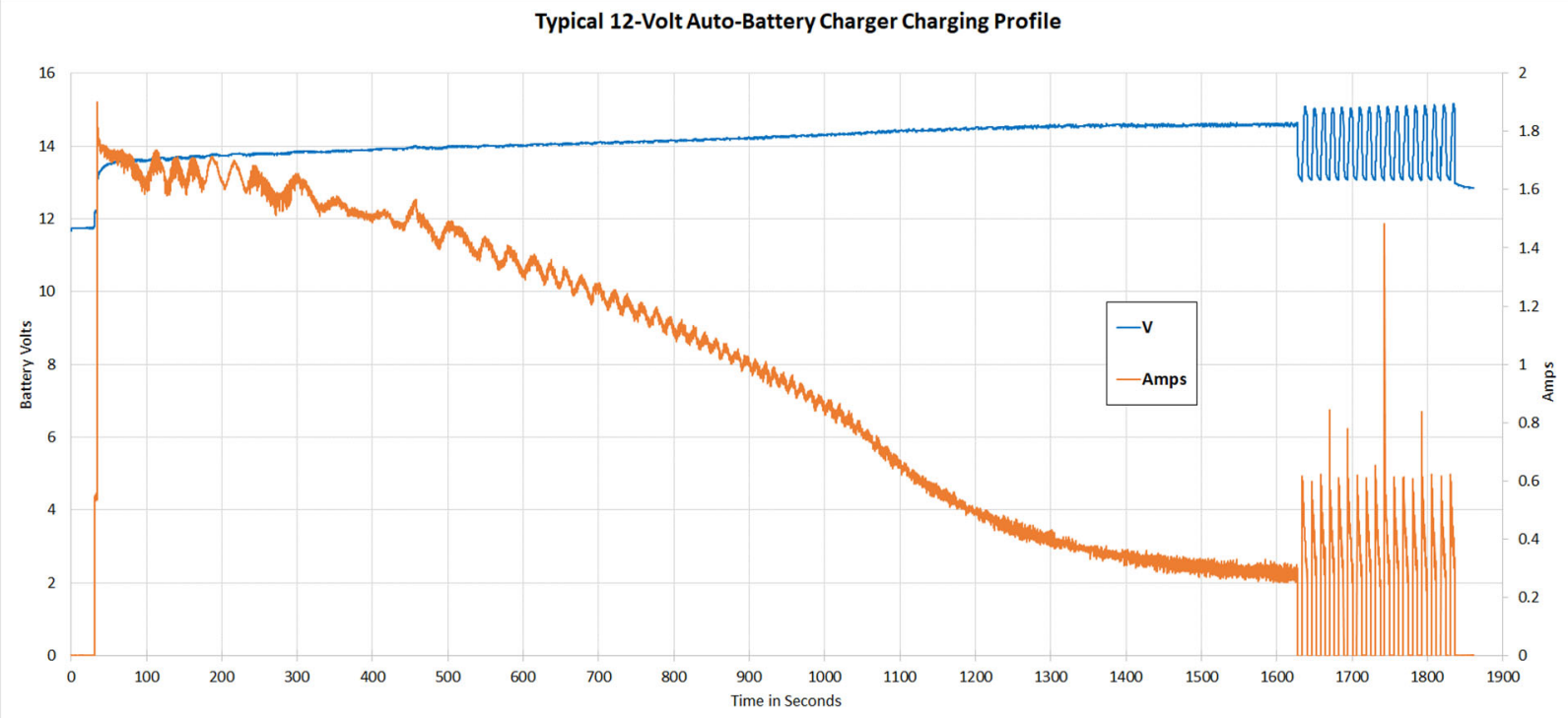

Figure 5: A typical battery charging profile using the Schumacker SC-600A automobile battery charger. Current and voltage are plotted against time in seconds. It is clearly evident that the charger goes into a pulsed "float mode" after 1600 seconds.

Assuming a 50\% discharge for two new comparable batteries in series yields $3.4 \mathrm{MJ}$ of usable energy. Reviewing the actual test data in Figure 6 below shows that two of the old batteries in series (24 volts) discharged at 113.7 watts over 17,435 seconds, yields an estimated 50\% battery capacity of $1.98 \mathrm{MJ}$, or a decrease in energy storage capacity of $\approx 43 \%$. Considering the cost of new batteries, the authors deemed this as acceptable for this project. 
Battery Discharge Volts Over Time at Various Discharge Wattages

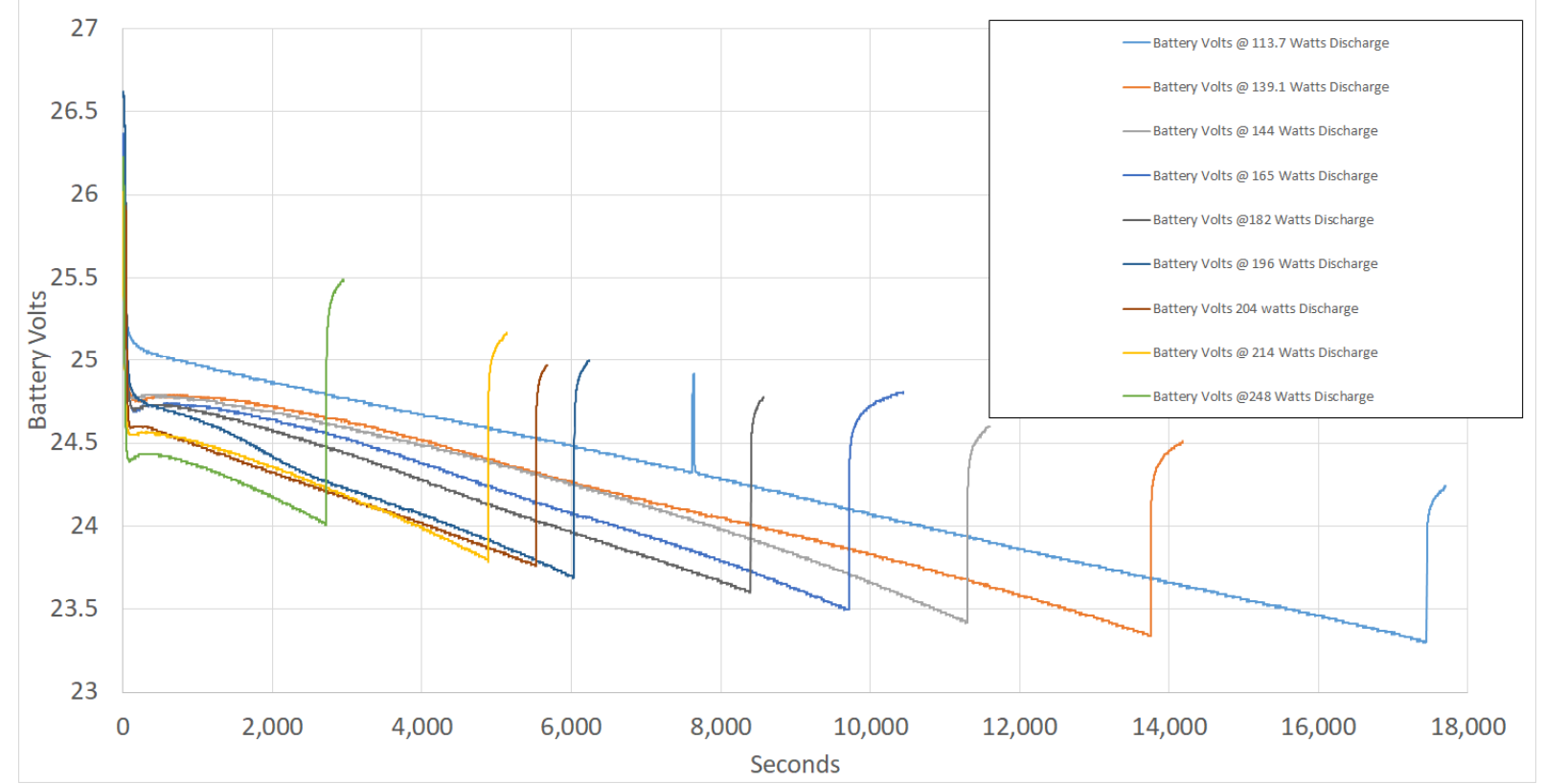

Figure 6: This graph shows time-to-discharge curves to approximately $50 \%$ state of charge for two Discovery batteries in series for a 24 volt system.

\section{System Design:}

When designing any electrical system one must determine the maximum current and power rating of its various constitutive components. The authors selected a Morningstar ProStar PSMPPT-25M; 25 amp 12/24 volt MPPT charge controller. This was purchased specifically for this project, and was selected primarily based on capabilities, but also its purchase price $(\$ 390)$. The maximum DC input voltage from the PV modules for the ProStar PS-MPPT charge controller is 120 volts. The typical PV module testing data we collected showed a $V_{o c} \approx 33$ volts, which might suggest that three of these modules in series could be used. This would be a serious error, as the modules are rated for $39.6 \mathrm{~V}_{\text {oc. }}$. Making corrections for Nominal Operating Cell Temperature (NOCT, see Appendix C for sample calculations), taking into account the possible high and low temperatures for the area Lawrence Tech is located, and using typical temperature coefficients for monocrystalline PV cells one quickly sees that new modules could display a maximum $V_{\text {oc }}$ values up to 46 volts [18] [19] [20] [21]. This results in limiting the input to two Isofoton I-94/24 PV modules in series. (Calculations for these values are found in Appendix C.)

Using similar calculations for maximum current, we see estimate maximum $I_{s c} \approx 3.4 \mathrm{amps}$. For wire run distances in this design it was estimated that $14 \mathrm{AWG}$ wires would be adequate. However, the modules have $12 \mathrm{AGW}$ wires, so for consistency and added safety, this design used 12 AWG wires throughout all current-carrying wired systems.

The goal of this portable PV power system was to have multiple power outputs, which include110 VAC, 12 VDC and 24 VDC. The Morningstar ProStar PS-MPPT charge controller provides 24 VDC output for power usage, as well as 12 VDC or 24 VDC optional output settings for battery charging. A Sinergex ${ }^{\text {TM }}$ PureSine ${ }^{2}$ 1500-124 inverter, which accepts 21 to 30 VDC 
power input to 110 VAC, was used for the VAC output. The Sinergex ${ }^{\mathrm{TM}}$ inverter has two 3prong NEMA 5-15R output plugs, and controls for auto shut-off should input voltage dropping below 21 volts or go above 30 VDC. This inverter was used in a previous project in 2007 and was not purchased for this project. The 12 VCD output is provided by a Mean Well SD-200B-12 $\mathrm{CD} / \mathrm{CD}$ converter, which was also available from a previous project.

\section{In-door System Bench Testing:}

To address the need to evaluate the system design during development over inconsistent, nonsunny, winter-weather months, an indoor bench test setup was assembled to confirm system operation. A Sorensen XG300-2.8 Programmable DC Power Supply (which could provide voltages and currents comparable to those anticipated by two Isofoton I-94/24 PV modules in series) was used to simulate PV module input. Because higher currents were possible from the charge controller into the batteries a $50 \mathrm{am} / 10 \mathrm{mV}$ current shunt (Crompton) was used in that leg of the circuit. Figure 7 below illustrates a schematic of the system used during bench test simulations. In addition, Figure 8 below shows a photo of the actual bench test hardware configuration in the lab.

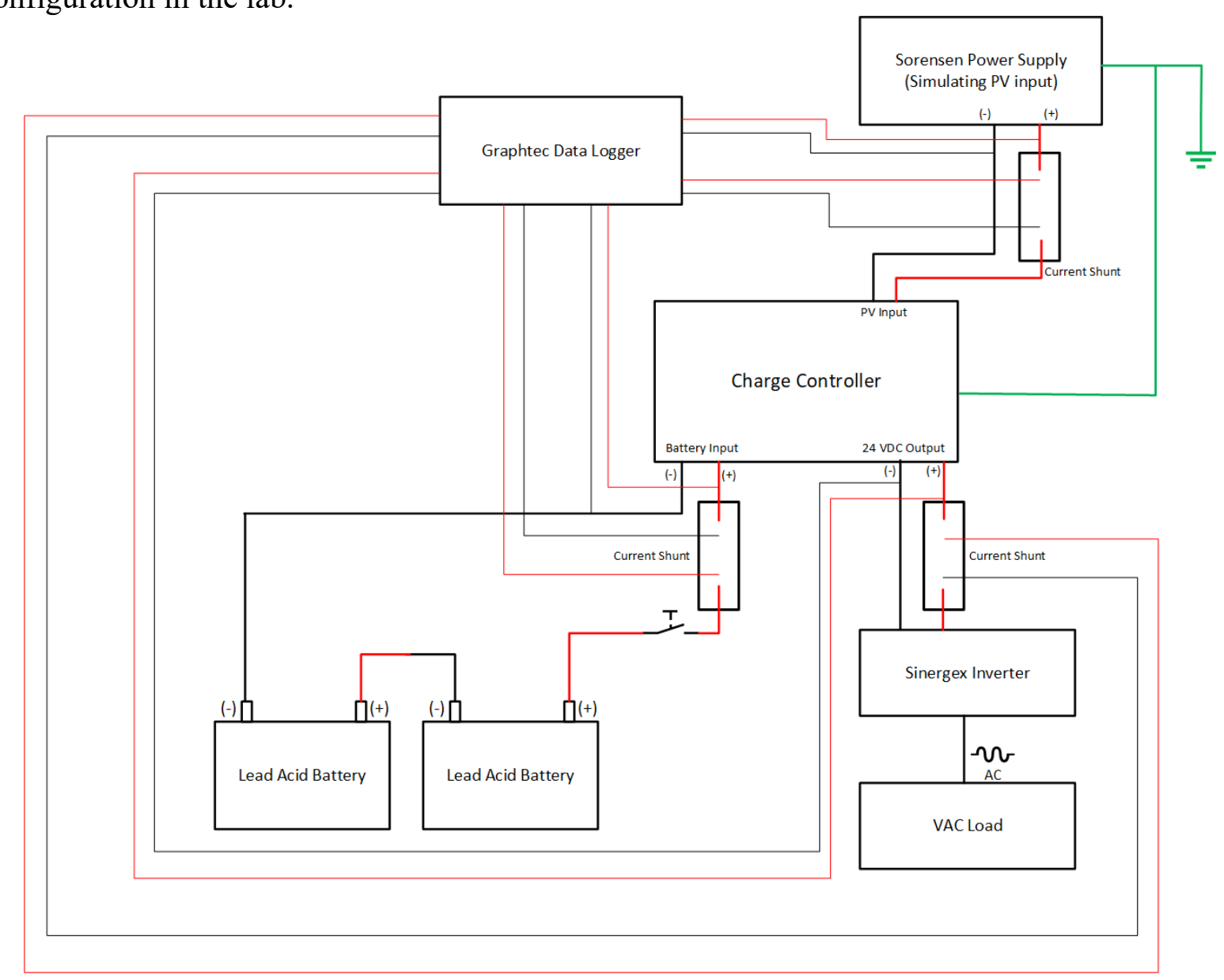

Figure 7: This shows the bench test simulation using the Sorensen power supply to simulate PV module input. 


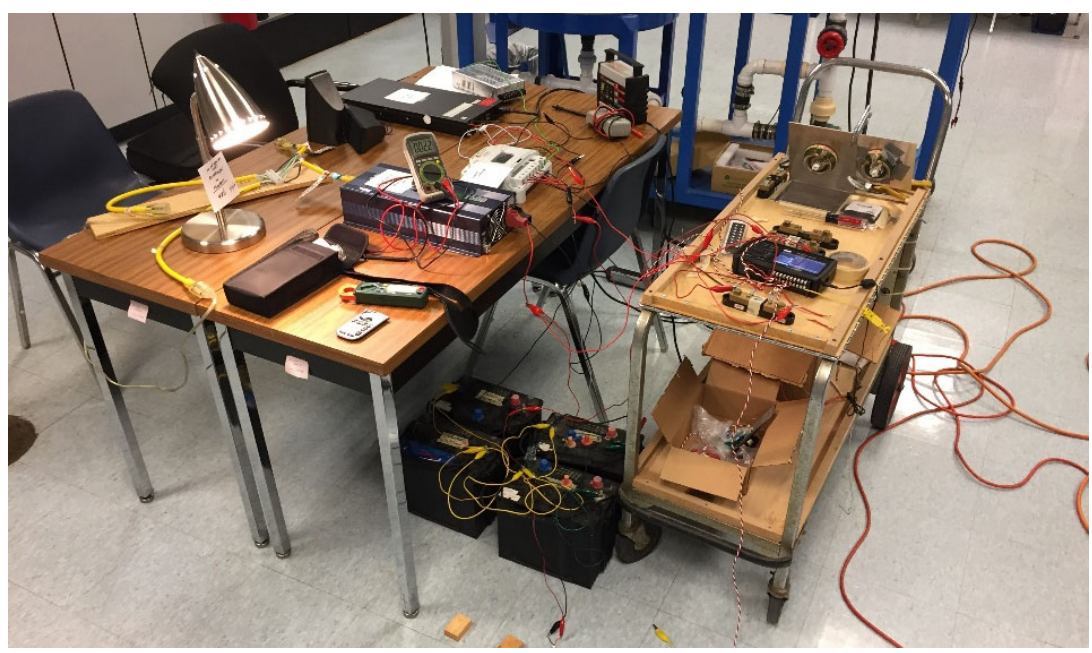

Figure 8: This shows the actual bench test simulation setup configuration in the lab to simulate PV module input. An incandescent lamp is used in this configuration as an AC load downstream from the inverter. To address safety concerns only authorized lab staff were allowed into the lab during these bench tests.

Several bench-test simulations were undertaken to assure all systems performed as required, and to also understand the interrelating dynamics of the charge controller, the power supply, inverter and batteries. An example of test data are plotted in Figure 9 below. The sequence of test steps are listed in the table imbedded in the graph of Figure 9.

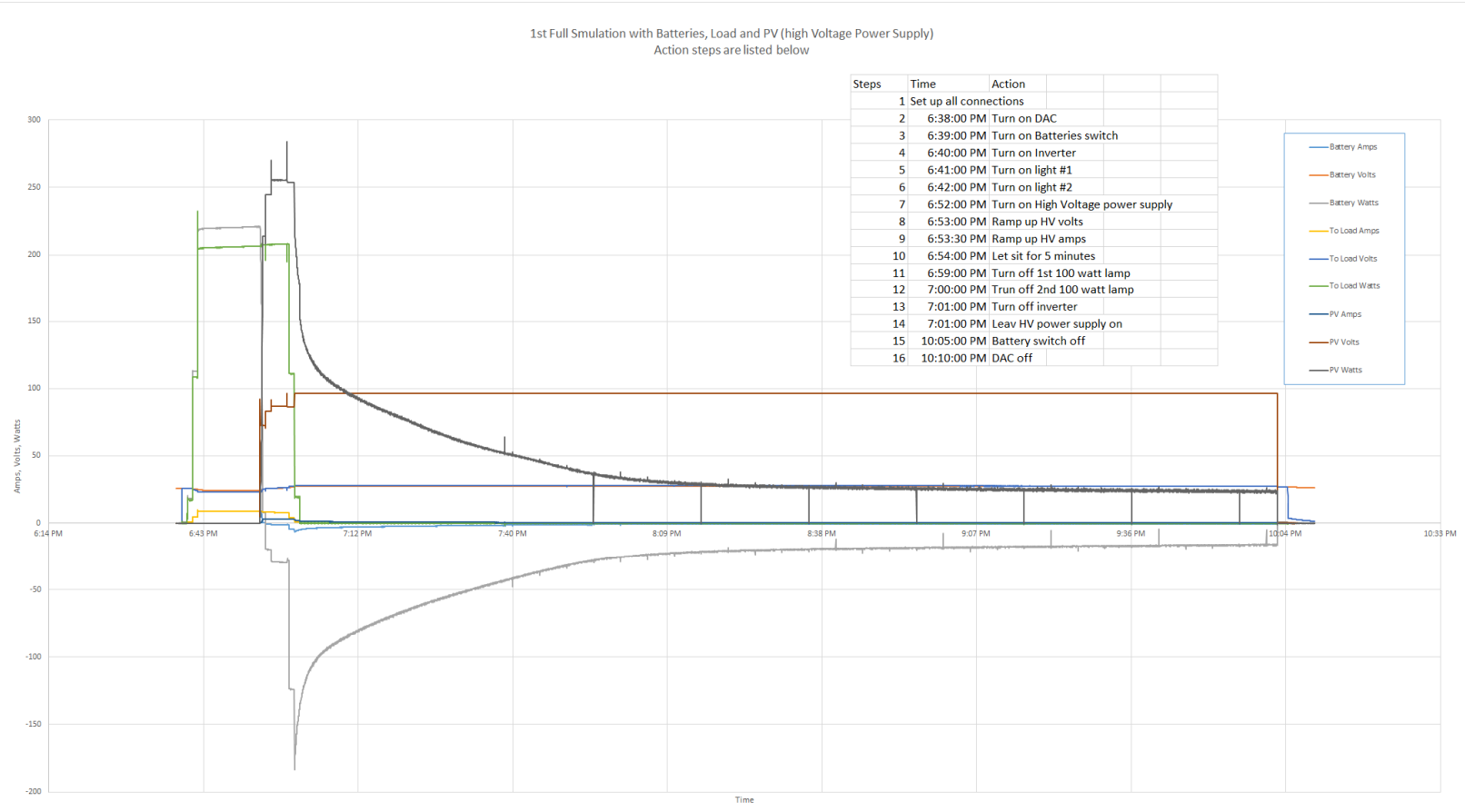

Figure 9: These data were collected from one of several bench tests using a power supply to simulate PV module input. Several step changes were carried out in this test and are listed in the table embedded in the body of the graph. 
Once bench tests were completed a series of outdoor solar tests were conducted. Initially, electrical connections were made, as before, using alligator clip jumper cables. $110 \mathrm{VAC}$ loads were obtained using incandescent lamps on a typical multi-plug extension cord plugged into the NEMA 5-15R inverter plug. Figure 10(A) and 10(B) below show the outdoor test setup. It should be noted that in Figure 10 three PV modules are shown, but only two were connected in series to provide power to the test system.

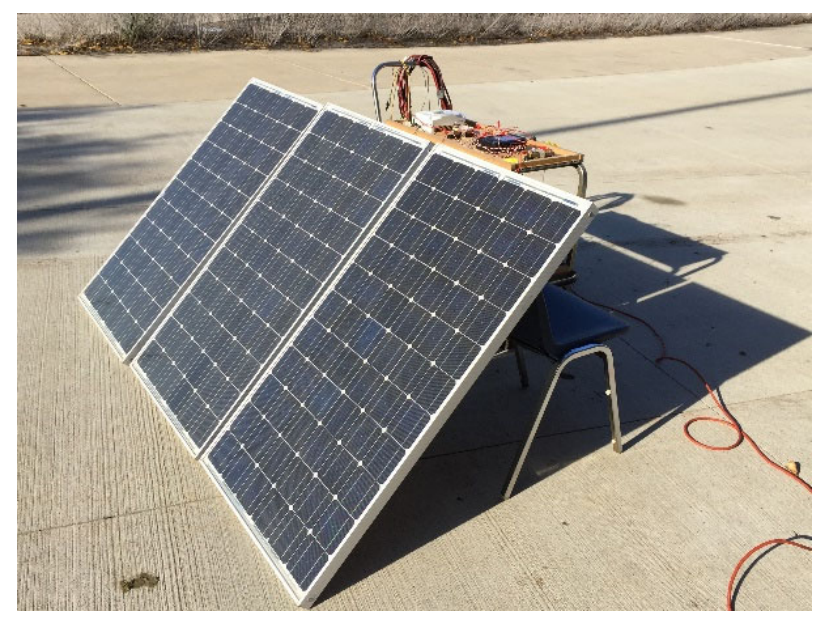

(A)

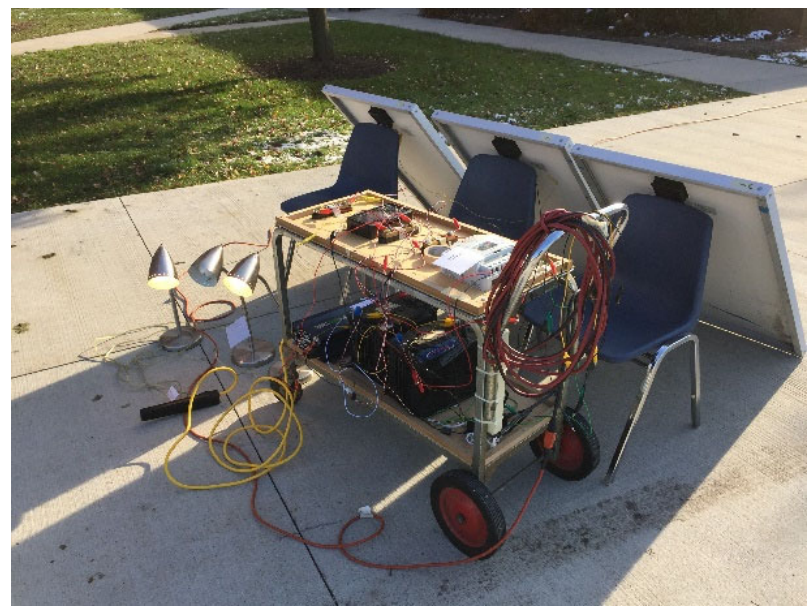

(B)

Figure 10: These two photos show one of the outdoor test setup configurations of the system. Figure 10(A) on the left shows the sun exposure side of the system. Figure 10(B) shows the rearside, including the data collection system. Two of the three incandescent lamps used as a load from the inverter are turned on in (B).

Data for the test conducted in Figure 10 above are provided in Figure 11. There were some fastmoving clouds that were passing overhead during this test yielding significant variation in power input from the PV modules. Insolation values ranged from $450 \mathrm{~W} / \mathrm{m}^{2}$ to $750 \mathrm{~W} / \mathrm{m}^{2}$. 


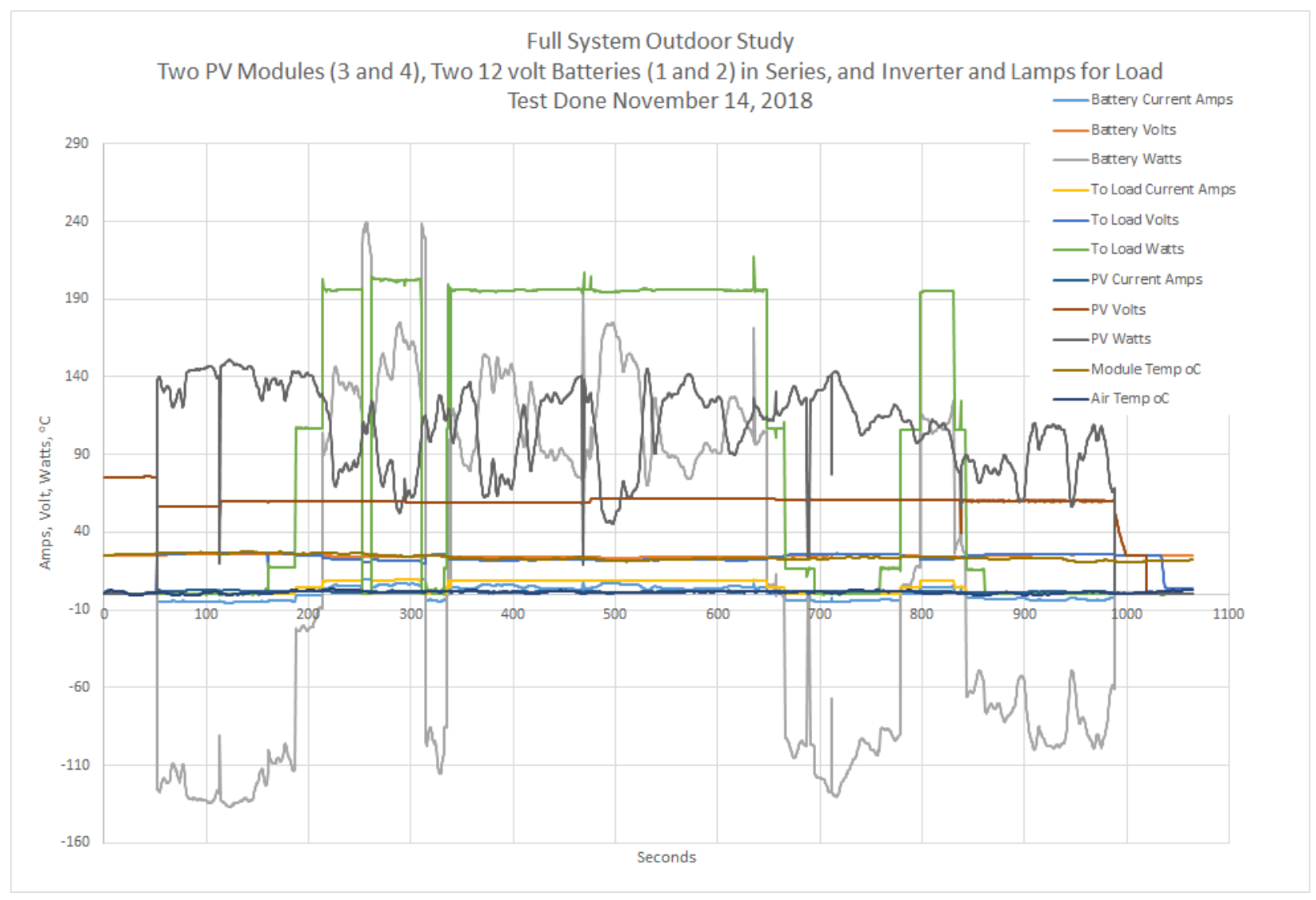

Figure 11: Shown here are data plotted from the test undertaken in Figure 10 above. Significant fluctuations can be seen in the PV watts due to rapidly moving high altitude clouds. Incandescent lamps were used as an alternating current load from the inverter.

\section{Preliminary Cart Prototype:}

A major goal of this project was to produce a small and manually mobile PV power system, with energy storage capacity and various forms of power output. The authors also wanted to make the system expandable for both added PV power generation, and added battery storage. A simple manually rolling prototype base-cart was designed and built. It has a simple clamping mechanism allowing for two PV modules on the cart that are electrically connected in series to tilt to the any solar angle. It is entirely made of scrap wood the faculty-author had in his lab or of disposed of wood from various on-campus construction projects.

The size and mobility of the portable cart is critical. When not used it will be stored in the engineering building. To be used it must be able to pass through internal building doorways, and also through building exits for transport outside. Also, the system requires a low center-ofgravity and a broad enough foot-print to assure that in case of any wind conditions during usage the cart is stable, and will not tip over from a PV module "sail-effect".

Another design goal was that it must also be easily and manually moved by one person. It must be easily positioned and oriented to the sun by one person, and it must be safely operated by a non-technical individual without risk of system damage, or electric shock. 
Lastly, the system must have minimal cost and flexible allowing for easy future redesign and modifications.

Figure 12 shows a photo of the student-co-author working in the university's wood shop making PV mounting brackets for the cart. Figure 13(A) and 13(B) show the basic prototype testing cart. A system low center of gravity was accomplished by installing all of the electrical components on, or very close to the base deck of the cart. Each 12 volt battery weighs 53 lbs., and the other hardware items (not including wiring) mounted weigh approximately an additional $50 \mathrm{lbs}$. The wood frame and wheels weighs approximately $75 \mathrm{lbs}$. But each module weighs $22 \mathrm{lbs}$, and has a large surface area that can catch the wind. The total weigh of the completed system is approximately $280 \mathrm{lbs}$. Intentional efforts by the authors to "tip over" the cart found it to be extremely stable with an adequately low center of gravity, and yet very easy to move and transport.

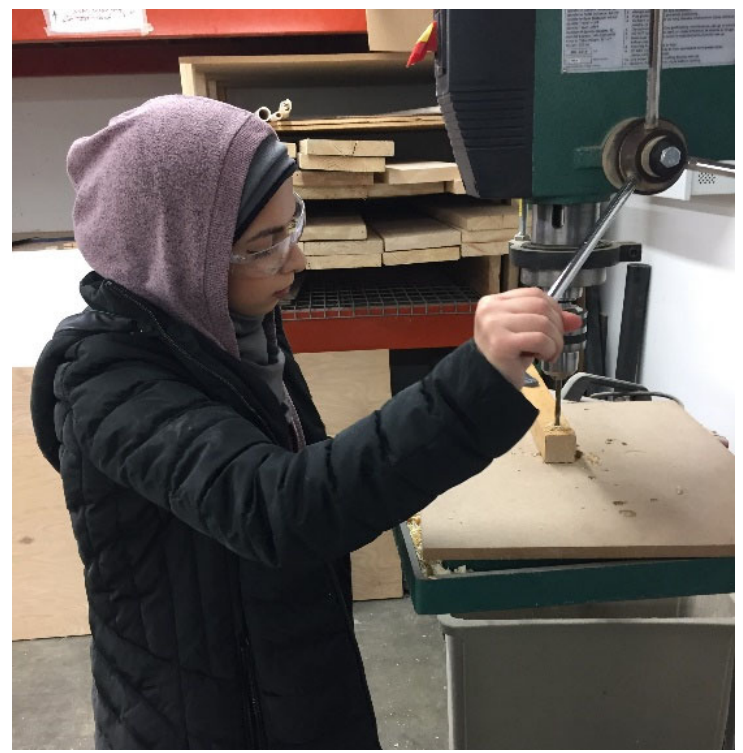

Figure 12: The student co-author of this paper is shown here making mounting brackets that hold the PV modules in place on the cart.

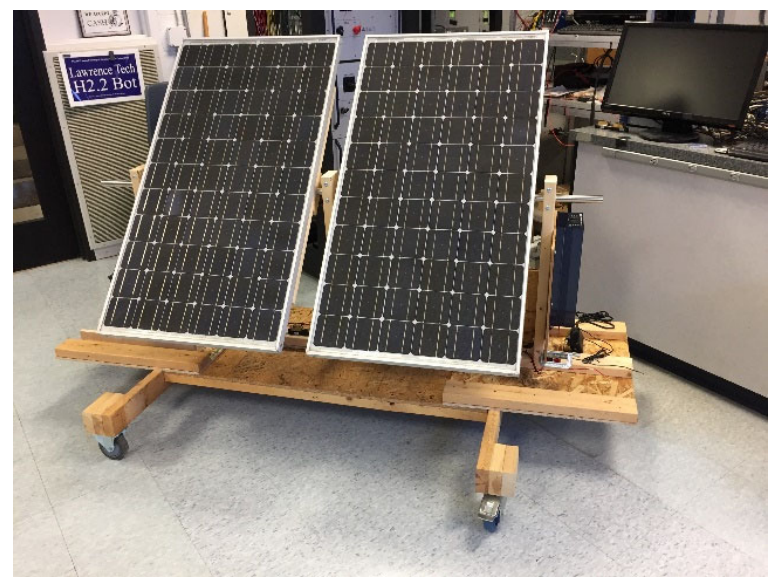

(A)

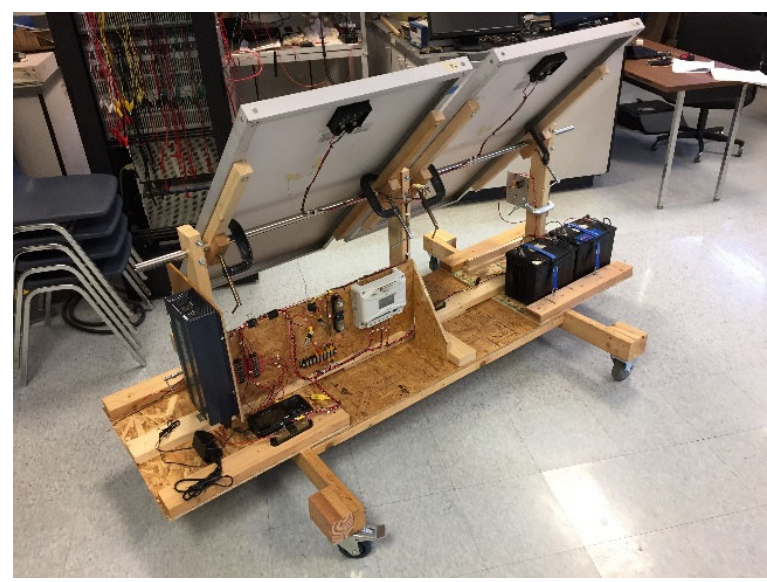

(B)

Figure 13: These photos show the front (A) and rear view of the (B) prototype test cart to be used for assessing other hardware mounting and wire runs for the final future design. 
A long-term future goal of this design is to also incorporate solar altitude and azimuth tracking capabilities. This system prototype (as illustrated in Figure 13 above) does not have that capability. But all equipment, components and wiring is installed on the prototype cart with the understanding of how it will work and function given that as a possible future option.

All non-module component mountings, such as batteries, charge controller, inverter, DC outputs, must not hinder module adjustment for solar angle, and also provide easy access when needed. That access must not result in casing shadows of any kind of the modules. Therefore, it was planned that all components would be fixed-mounted low on the cart deck to improve system center-of-gravity, and on the system rear-side, as seen in Figure 13(B). Because module tilt angle is adjustable, all electrical connections must be flexible and be routed along the swivel axis.

A preliminary design circuit has been developed and installed on the cart. It is illustrated in Figure 14 below. This preliminary prototype will not be used in wet weather, however it still requires adequate grounding. The NEC, Article 690, has detailed guidelines for circuit design, fusing and grounding for building and stand-alone PV systems [22]. It does not, however, provide guidance for a design such as in this project. Other projects documented on YouTube show several systems (some which are well over 100 volts, and DC currents above $100 \mathrm{~mA}$ which can be fatal) with no grounding. This is an inherent safety risk. The proposed design will use an electrical grounding cable connected to the physical earth/soil, or other sufficient grounding source, to serve as a functional common ground. The actual system circuit wiring, charge controller and current shunts for the test cart configuration are shown in Figure 15. 


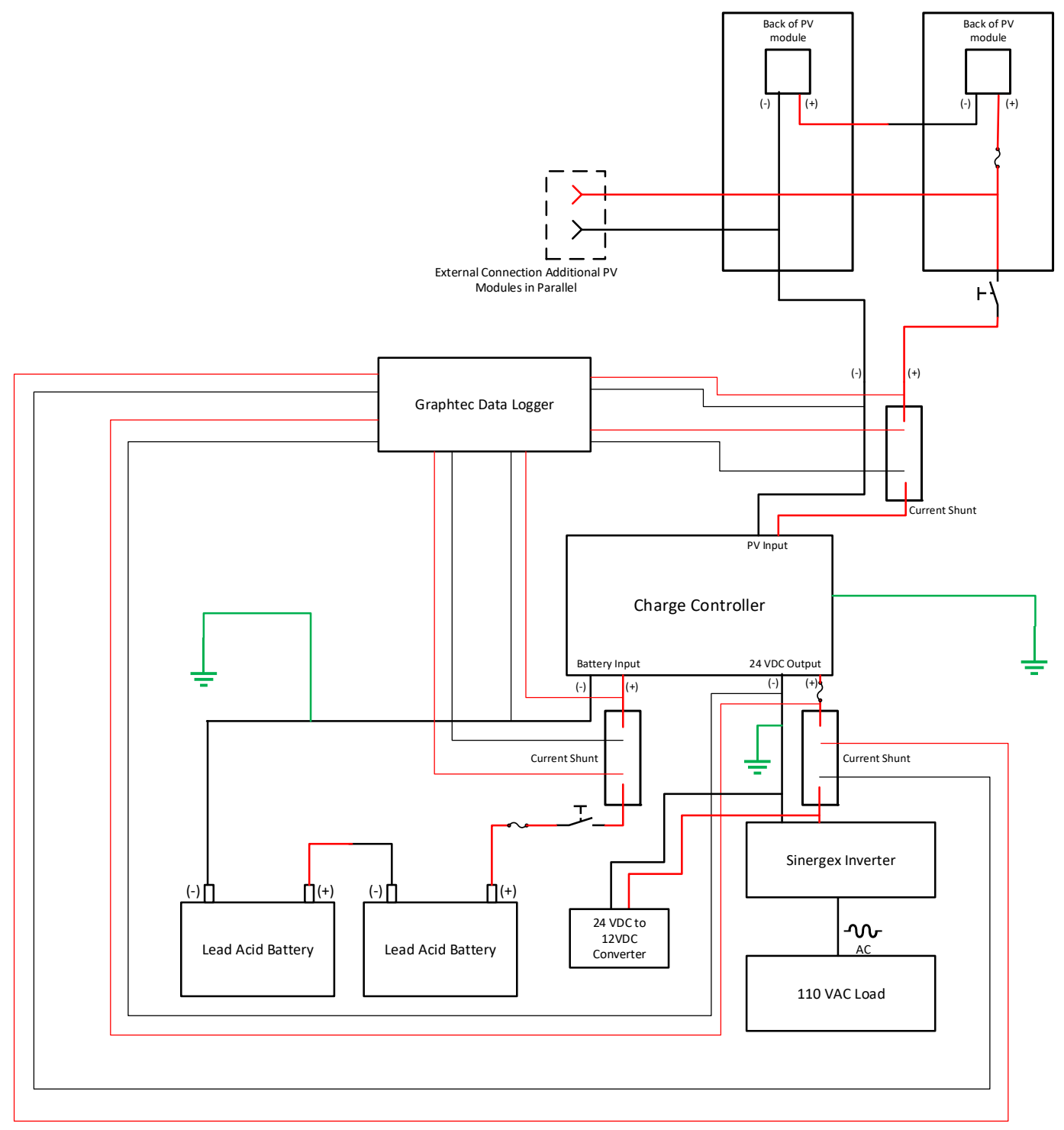

Figure 14: The preliminary electrical wiring and component schematic of the prototype PV energy storage cart. 


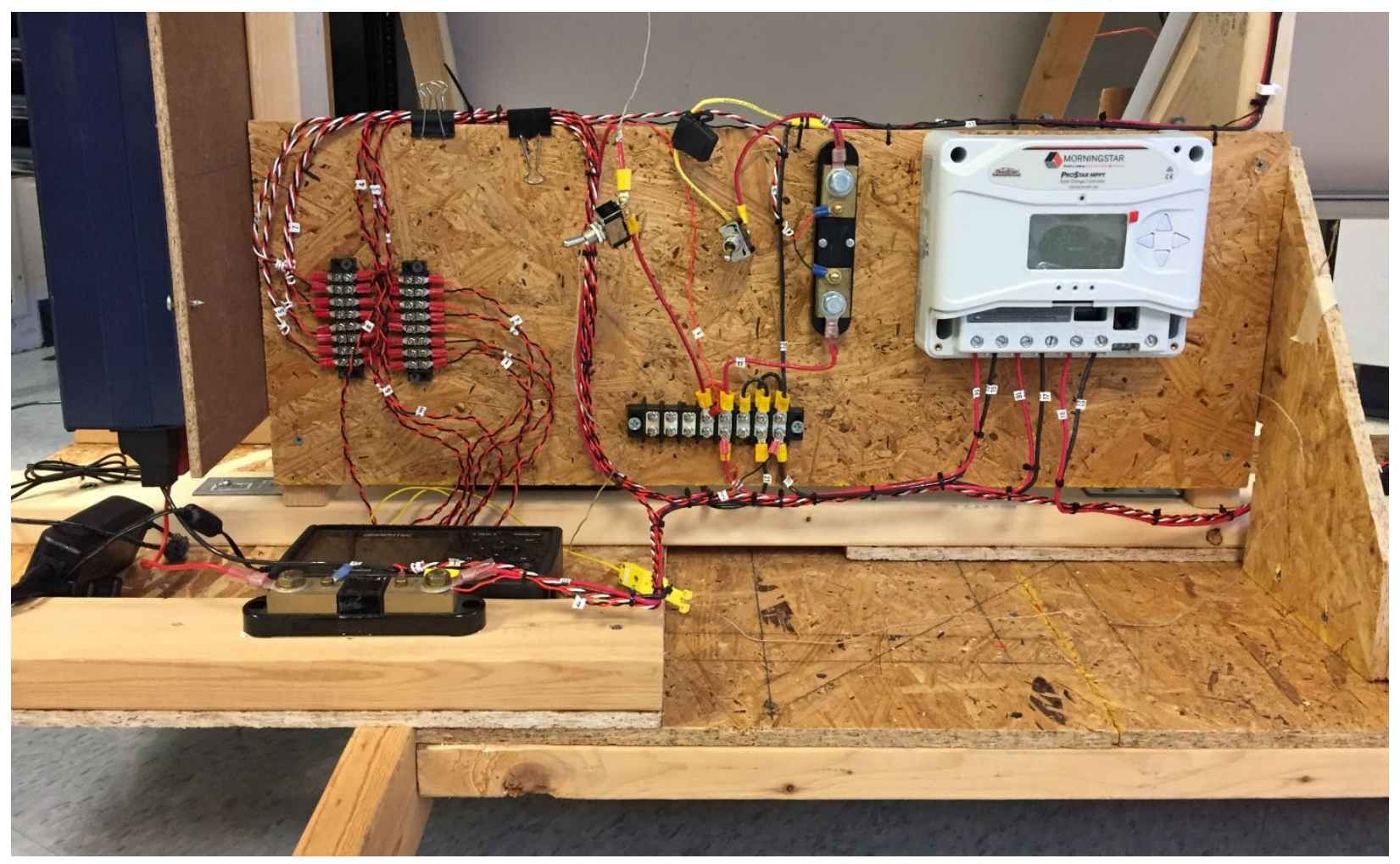

Figure 15: A detailed photo of the circuit wiring, charge controller and current shunts for the test cart configuration.

The base cart will eventually have the capability to stow four additional PV modules for system expansion. For use these added modules will be manually removable from the cart, self-equipped with simple tripod feet and manually set-up next to the cart, and using an external parallel-circuit flexible umbilical wire-harness cable and connecting plug to the on-cart charge controller. This will yield additional power input from the four stowed modules, for a total of six PV modules providing power (three sets of modules in parallel with two modules in series in each parallel set). Each series set of modules will be properly fused and grounded to assure safe operation. This configuration has now been successfully tested using jumper cables (but without the final designed wiring harness and without the final tripod feet installed). Figure 16 shows this testing setup.

To evaluate system performance the Graphtec data logger was used to measure current, voltages as well as ambient air and PV module temperatures. The MorningStar charge controller has its own battery temperature monitoring and temperature compensation installed. 


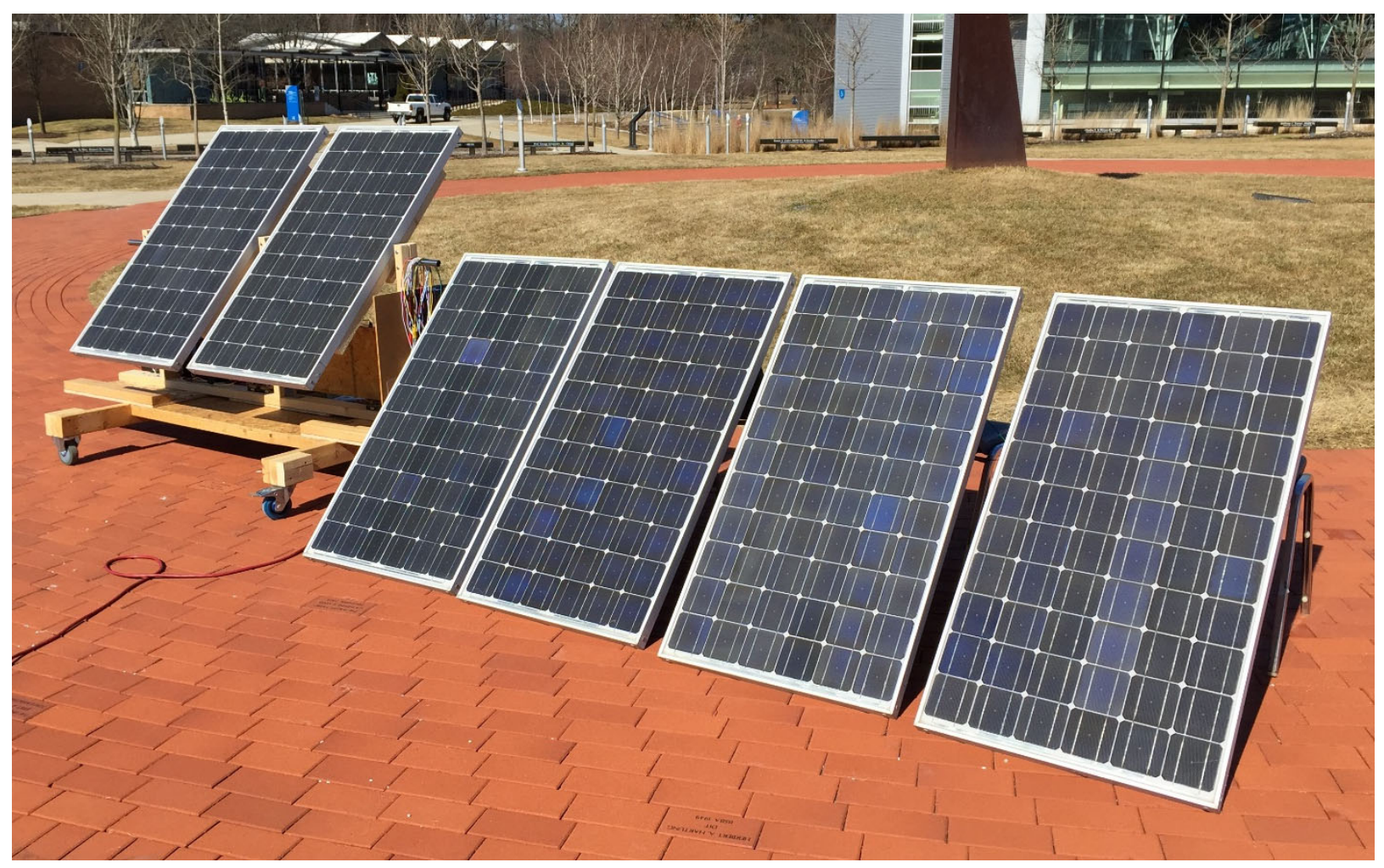

Figure 16: The six module system using the two modules mounted on the base cart with additional power input from the four stowed modules (the four modules to the right of the cart), for a total of six PV modules providing power with three sets of modules in parallel with two modules in series in each parallel set. Circuit connections for the set-up shown here were made using temporary jumper cables for the four modules that will be stowed on the cart.

\section{Educational Plan For This System}

The PV solar energy storage cart project fits well with Alternative Energy Engineering course and program at Lawrence Tech. The most beneficial are the school's Alternative Energy Engineering graduate course, and the Solar Energy Engineering graduate course, both of which can be taken by undergraduate seniors in engineering (who meet course prerequisites), as well as graduate engineering students.

It will also be used in various areas of study for student interested in solar photovoltaic system design, and systems engineering. Specific academic curriculum and activities have yet to be developed but will be completed during the summer of 2019 once the testing system performance has been fully characterized. But some of the intended activities for use, however, are listed below.

Besides the student's experience gained during the process of designing and building the solar power project, this system will also be used as a lab model for the students from different colleges (Colleges of Architecture, Arts and Sciences) to demonstrate the different performance and operational aspects of PV technology. 
We intend to use this solar power and energy storage cart as a testing system for collecting data and use those data as reference for other different academic research that is ongoing at Lawrence Tech and related to the same field. It can be used as an educational example to discuss its integrated design, circuitry design, safety considerations, and basic solar PV system installation.

We will explore how this project can be used to study the effects of the weather and environmental changes on the performance of the PV modules and other parts of the system. The impacts due to changes in operational parameters like temperature, light intensity, or angles of incidence of the sunlight can easily be examined using this portable solar cart.

This project is an integrated electrical and power device that can be used to perform different experiments to measure and compare theoretical values versus practical values of many different physical properties like power, voltage, temperature, and current.

The data collected using the data acquisition device provide an excellent educational opportunity giving students an opportunity to study the relations between the different components of the solar systems and the energy consumption required to operate these components.

\section{Future Work:}

There are several areas open to future work on this project. The most immediate being adding additional external electrical plugs allowing the integration of the four additional external PV modules. The base cart also still needs to be modified to safely stow and support these four modules so that these additional modules are not damaged during cart movement. The authors are confident the system will perform as intended, based on bench testing, and out-door solar testing. The goal is to have these items completed in the spring 2019 academic semester to allow a full range of system tests in the late spring and early summer.

Additional assessment will be done to add the two remaining lead-acid batteries to expand energy storage.

A full and complete testing plan for the system also needs to be defined to fully characterize the system performance. This then can serve as a data baseline for future educational lab activities for students.

The last aspect of this effort could be to involve weather-proof the system, circuity, and data acquisition systems so that it, if desired, could be left outside for prolonged periods of time. The concern about electrical safety and adequate grounding remain as more modules will be added. This is an area in the future for extensive literature searches to learn about best practices. The longer term, out-door option will require more attention with the intent of adding PV solar tracking, this increasing power production.

The authors intend to document this future work, and present those future efforts at the coming ASEE conference in 2020. 


\section{Student Experience and Knowledge Gained:}

(The following is a review and the personal thoughts about this project by the student worker who assisted in the design, build, and testing of the PV cart, and also co-authored this paper.)

"I am an undergraduate student assisting in design and building of the portable solar power project. My work on the project extended beyond my discipline curriculum and I believe it has a great impact on improving my professional skills preparing me for my future career.

While participating in this project, I had the opportunity to practice and integrate much of the knowledge I learned during my three years of course work as an undergraduate student. Working in the renewable energy lab in a team of two with an expert professor, enhanced my communication abilities; team working skills; and added a valuable experience that I could not obtain during my usual course work.

Throughout the time I spent working on this project, I had the chance to express my ideas and think critically and independently in solving related problems. In addition to the previous general valuable skills, I learned specific lab testing techniques, where I performed many different tests that I never had done before. I learned how to use the data acquisition system for temperature, current and voltage data collection. I also learned about the charge controller which served as a main control unit while testing the photovoltaic modules and batteries performances, the DC/AC inverter to supply different load systems, mechanical/electrical relays as switches, voltage and current regulators (for the current using current shunts), and many other important electrical devices and lab tools. During and after the process of collecting the tests data, I had the chance to analyze the collected data independently and review the result with my supervisor.

Before starting the work in the solar project, I had no chance to practice design and build circuits on a large scale. I also had no laboratory or research experiences with batteries or PV systems prior to this. Throughout my participation in the solar energy project, I gained knowledge about the electrochemical dynamics of lead-acid batteries; physical and electrical performance characteristics of the PV modules; and basic knowledge about installing energy-storage solar systems.

Working on these kinds of projects and research is encouraged and recommended for any undergraduate student. I personally recommend spending more time working in a similar academic project like the solar power project. The experience I gained during working in this project is equivalent to the work experience gained in any undergraduate internship opportunity."

\section{Summary and Conclusions:}

A portable PV power system has been proposed, designed, fabricated, and physically tested, we have demonstrating its ability to deliver 110 volts AC, and both 24 volt DC and 12 volt DC 
output power to the user when it batteries are fully charged. A prototype test cart has been built with the intent of outfitting it as a stand-alone system. The portable cart, holds all the system components, and is also made of materials that were on-hand from previous Lawrence Tech projects. Several of the main operational components in this system were previously used, recycled, and/or repurposed materials, such as the PV modules and batteries, thus, significantly lowering the project cost.

Another important aspect of this project is that the PV power source is expandable. The basic stand-alone cart has two PV modules (approximately 100-watts each), but the design also allows for adding additional PV modules to provide greater solar source power for quicker battery charging, or more day-time external power delivery. The system will also be expandable to incorporate additional as-needed battery storage.

This project, based on documented student feedback, has been a beneficial educational experience for the student involved. It will also serve as an educational solar PV demonstration testing system to help engineering students gain the opportunity to use, learn and understand the operational dynamics of a complete PV system containing photovoltaic modules, charge controller, storage batteries, and various power outputs including $110 \mathrm{VC}, 12 \mathrm{VDC}$ and $24 \mathrm{VDC}$. The simple data acquisition system tracks current and voltages for the PV, battery and power output components, as well as module and ambient air temperatures. These features allow the student to assess temperature effects of both PV and battery performance characteristics.

It has also given the College of Engineering at Lawrence Tech a new approach for how to develop and complete meaningful projects at very low up-front cost. This approach may be a viable one for other engineering schools.

Lastly, this system can serve as a demonstration prototype illustrating how to potentially re-use older PV modules for possible low-income, or limited power access areas at minimal expense.

Based on these efforts the project has now since been reviewed by other LTU engineering faculty and College of Engineering administration staff, and has deemed a success, as well as a valuable addition to the Alternative Energy lab resources to be used in the future to help educate Mechanical, Electrical and Architectural Engineering students within the college.

\section{References:}

[1] Fletcher, R. W. (2011, June), A Seven-Year Review and Assessment of Lawrence Technological University's Alternative Energy Engineering Program Initially Funded Through Grants From the State of Michigan Paper presented at 2011 ASEE Annual Conference \& Exposition, Vancouver, BC.

[2] MASCO Corporation website; http://masco.com; [on-line], last accessed January 25, 2019.

[3] The Battery university website;

https://batteryuniversity.com/learn/article/how_to_restore_and_prolong_lead_acid_batteries; [on-line], last accessed January 25, 2019.

[4] The Instructables website; https://www.instructables.com/id/How-to-revive-old-lead-acidbatteries/; [on-line], last accessed January 25, 2019. 
[5] Battery Recovery, Battery Reconditioning, Battery Desulfation and Battery Maintenance... Made Easy!; https://www.recovermybatteries.com/batterybasics1.html; [on-line], last accessed Janaury 25, 2019.

[6] Sungwoo Choi, et al; Performance degradation due to outdoor exposure and seasonal variation in amorphous silicon photovoltaic modules; Thin Solid Films, Volume 661, September 2018, Pages 116-121.

[7] Nabil Kahoul, et al; Evaluating the reliability of crystalline silicon photovoltaic modules in harsh environment; Renewable Energy, Volume 109, August 2017, Pages 66-72

[8] Ababacar Ndia, et al; Degradations of silicon photovoltaic modules: A literature review; Solar Energy, Volume 96, October 2013, Pages 140-151.

[9] Saïcha Gerbinet, et al; Life Cycle Analysis (LCA) of photovoltaic panels: A review; Renewable and Sustainable Energy Reviews; Volume 38, October 2014, Pages 747-753 [10] Billy Ludt; Old solar panels get second life in repurposing and recycling markets; Solar Power World [online]; https://www.solarpowerworldonline.com, January 9, 2019; last accessed January 25, 2019.

[11] Karim Ghaiba, Fatima-Zahrae, and Ben-Fares; A design methodology of stand-alone photovoltaic power systems for rural electrification; Energy Conversion and Management Volume 148, 15 September 2017, Pages 1127-114.

[12] Francesca Poggia, Ana Firminoa and Miguel Amado; Planning renewable energy in rural areas: Impacts on occupation and land use; Energy, Volume 155, 15 July 2018, Pages 630-640. [13] Susanne Gooijer, et al; Shading of solar cells - The influence of shading on commercial solar cell performance; PWS, October 24th 2016

[14] Solar Edge Technical Note: Technical Note Bypass Diode Effects in Shaded Conditions, [15] Alternative Energy Tutorials [online]; http://www.alternative-energy-tutorials.com/energyarticles/bypass-diode.html; last accessed March 12, 2019.

[16] Zhang, Z., Wohlgemuth J., Kurtz, S.; The thermal reliability study of bypass diodes in photovoltaic modules; PV Module Reliability Workshop, February 26 - 27 2013, Golden, Colorado; National Renewable Energy Laboratory, Golden, Colorado, USA

[17] Narendra Shiradkar, et al; Model for predicting thermal runaway in bypass diodes; 2014 IEEE 40th Photovoltaic Specialist Conference (PVSC)

Date of Conference: 8-13 June 2014.

[18] National Renewable Energy Laboratory, Solar Radiation Data Manual for Flat-Plate and Concentrating Collectors, National Renewable Energy Laboratory, Golden, Colorado.

[19] Morningstar Professional Series, ProStar MPPT Operator's Manual.

[20] Roger Messenger, Jerry Venture; Photovoltaic Systems Engineering; page 123, Third Edition, CRC Press, Taylor and Francis Group, Boca Taton, FL, 2010.

[21] David L. King, et al; Temperature Coefficients for PV Modules and Arrays: Measurement Methods, Difficulties, and Results; $26^{\text {th }}$ IEEE Photovoltaic Specialists Conference, September 1997, Anaheim, California.

[22] National Electrical Code 2017 by (NFPA) National Fire Protection Association, Article 690, Solar Photovoltaic (PV) Systems, Quincy, Massachusetts. 


\section{APPENDIX A}

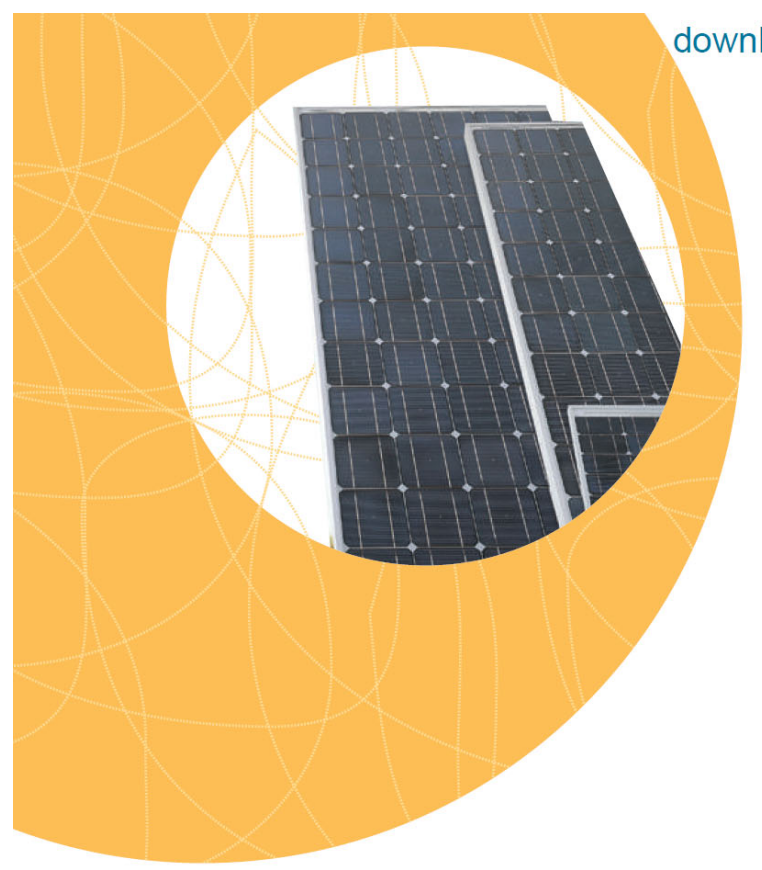

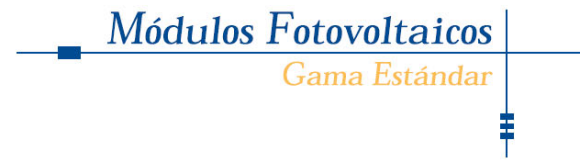

Ed. Mayo 2004 
downloaded from www.photovoltaik-web.de

\begin{tabular}{|c|c|c|c|c|c|c|c|c|}
\hline & $\mathrm{I}-5$ & $\mathrm{I}-10$ & $\mathrm{I}-22$ & $\mathrm{I}-36$ & $\mathrm{I}-47$ & $\mathrm{I}-50$ & $\mathrm{I}-55$ & $\mathrm{I}-65$ \\
\hline \multicolumn{9}{|l|}{ CARACTERÍSTICAS FÍSICAS } \\
\hline Dimensiones (mm) & $270 \times 270 \times(*)$ & $370 \times 336 \times(*)$ & $540 \times 440 \times(*)$ & $629 \times 532 \times 39,5$ & $1.208 \times 340 \times 39,5$ & $1.304 \times 340 \times 39,5$ & $1.304 \times 340 \times 39,5$ & $1.224 \times 545 \times 39,5$ \\
\hline Peso & $0,8 \mathrm{~kg}$ & $1,8 \mathrm{~kg}$ & $3 \mathrm{~kg}$ & $4,5 \mathrm{~kg}$ & $5,5 \mathrm{~kg}$ & $5,5 \mathrm{~kg}$ & $5,5 \mathrm{~kg}$ & $9 \mathrm{~kg}$ \\
\hline Número de células en serie & $321 / 8$ & $361 / 4$ & $361 / 2$ & $361 / 2$ & 33 & 36 & 36 & 36 \\
\hline Número de células en paralelo & 1 & 1 & 1 & 1 & 1 & 1 & 1 & 1 \\
\hline TONC $\left(800 \mathrm{~W} / \mathrm{m}^{2}, 20^{\circ} \mathrm{C}, \mathrm{AM} 1.5, \mathrm{Im} / \mathrm{s}\right)$ & $40^{\circ} \mathrm{C}$ & $40^{\circ} \mathrm{C}$ & $47^{\circ} \mathrm{C}$ & $47^{\circ} \mathrm{C}$ & $47^{\circ} \mathrm{C}$ & $47^{\circ} \mathrm{C}$ & $47^{\circ} \mathrm{C}$ & $47^{\circ} \mathrm{C}$ \\
\hline $\begin{array}{l}\text { Tipo de célula: Si monocristalino, texturada } \\
\text { y con capa antirreflexiva (mm) }\end{array}$ & $103 \times 103$ & $103 \times 103$ & $103 \times 103$ & $125 \times 125$ & $103 \times 103$ & $103 \times 103$ & $103 \times 103$ & $125 \times 125$ \\
\hline \multicolumn{9}{|l|}{$\begin{array}{l}\text { CARACTERÍSTICAS ELÉCTRICAS } \\
\left(1.000 \mathrm{~W} / \mathrm{m}^{2}, 25^{\circ} \mathrm{C} \text { célula, AM } 1.5\right)\end{array}$} \\
\hline Tensión nominal $\left(V_{n}\right)$ & $12 \mathrm{~V}$ & $12 \mathrm{~V}$ & $12 \mathrm{~V}$ & $12 \mathrm{~V}$ & $12 \mathrm{~V}$ & $12 \mathrm{~V}$ & $12 \mathrm{~V}$ & $12 \mathrm{~V}$ \\
\hline Potencia máxima $\left(P_{\operatorname{maxx}}\right)$ & $5 W_{p} \pm 10 \%$ & $10 \mathrm{~W}_{\mathrm{p}} \pm 10 \%$ & $22 \mathrm{~W}_{\mathrm{p}} \pm 10 \%$ & $36 \mathrm{~W}_{\mathrm{p}} \pm 10 \%$ & $47 \mathrm{~W}_{p} \pm 10 \%$ & $50 \mathrm{~W}_{\mathrm{p}} \pm 10 \%$ & $55 W_{p} \pm 10 \%$ & $65 \mathrm{~W}_{\mathrm{p}} \pm 10 \%$ \\
\hline Corriente de cortocircuito $\left(\mathrm{I}_{\mathrm{s}} \mathrm{d}\right.$ & $0,41 \mathrm{~A}$ & $0,82 \mathrm{~A}$ & $1,64 \mathrm{~A}$ & $2,22 \mathrm{~A}$ & $3,27 \mathrm{~A}$ & $3,27 \mathrm{~A}$ & $3,38 \mathrm{~A}$ & $4,37 \mathrm{~A}$ \\
\hline Tensión de circuito abierto ( $\left(\mathrm{b}_{0}\right)$ & $19,2 \mathrm{~V}$ & $21,6 \mathrm{~V}$ & $21,6 \mathrm{~V}$ & $21,6 \mathrm{~V}$ & $19,8 \mathrm{~V}$ & $21,6 \mathrm{~V}$ & $21,6 \mathrm{~V}$ & $21,6 \mathrm{~V}$ \\
\hline Corriente de máxima potencia $\left(I_{\text {maxx }}\right)$ & $0,32 \mathrm{~A}$ & $0,58 \mathrm{~A}$ & $1,26 \mathrm{~A}$ & $2,1 \mathrm{~A}$ & $2,94 \mathrm{~A}$ & $2,87 \mathrm{~A}$ & $3,16 \mathrm{~A}$ & $3,76 \mathrm{~A}$ \\
\hline Tensión de máxima potencia ('háx.) & $15,5 \mathrm{~V}$ & $17,4 \mathrm{~V}$ & $17,4 \mathrm{~V}$ & $17,2 \mathrm{~V}$ & $16 \mathrm{~V}$ & $17,4 \mathrm{~V}$ & $17,4 \mathrm{~V}$ & $17,3 \mathrm{~V}$ \\
\hline
\end{tabular}

Una opción de futuro para la producción

de electricidad a partir de la energía

solar que respeta el medio ambiente

Todos los módulos marca Isofotón pueden ser garantizados por un periodo máximo de 25 años (consultar condiciones en www.isofoton.com).

Nota: Isofotón, S.A., se reserva el derecho a introducir cambios en este folleto sin previo aviso.

Todos los módulos fotovoltaicos pueden ser suministrados en versión laminado (Código Modelo Versión Laminado: Lm seguido del modelo del módulo).

(*) Por favor, consulte el espesor antes de realizar un pedido.

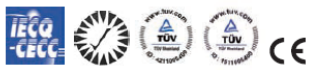

downloaded from www.photovoltaik-web.de

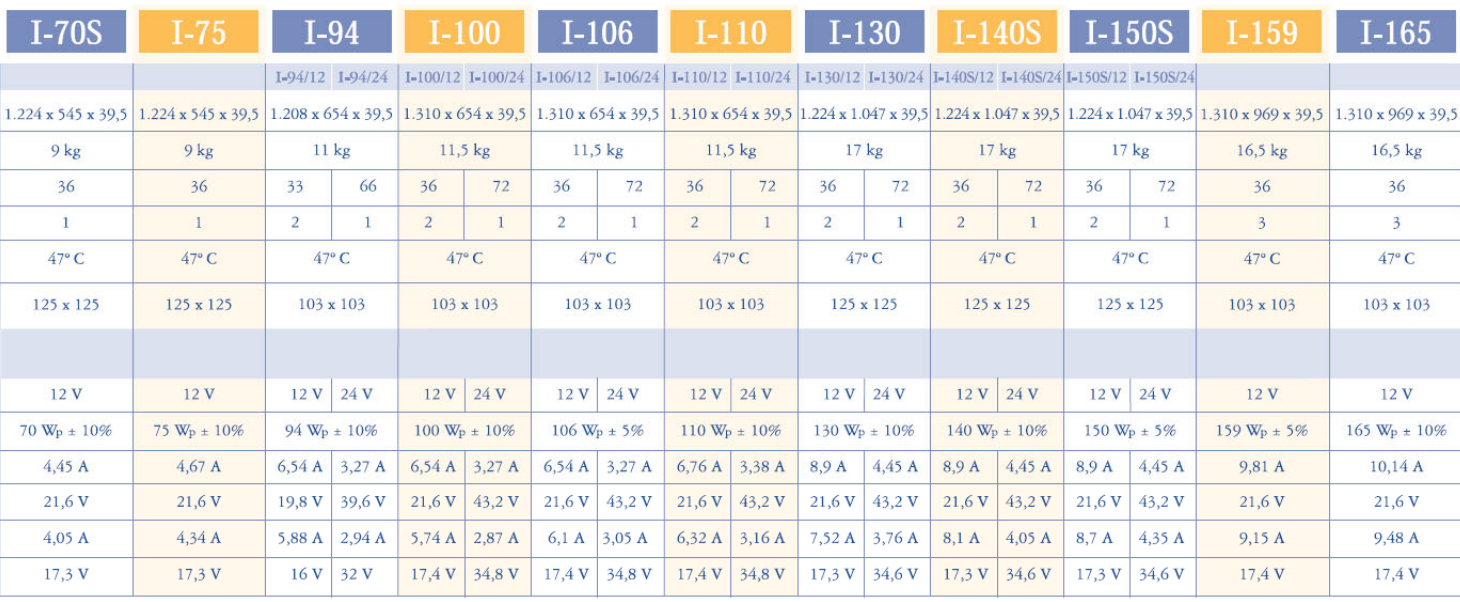

\begin{tabular}{|l|c|}
\hline \multicolumn{2}{|c|}{ CARACTERÍSTICAS CONSTRUCTIVAS } \\
\hline Contacto* & Contactos redundantes, múltiples, en cada célula \\
\hline Laminado* $^{*}$ & EVA (etilen-vinil acetato) \\
\hline Cara frontal & Vidrio templado de alta transmisividad \\
\hline Cara posterior & Protegida con Tedlar de varias capas \\
\hline Marco* & Aluminio anodizado \\
\hline
\end{tabular}

\begin{tabular}{|l|c|}
\hline I-36 I-47 I-50 I-55 I-65 I-705 I-75 I-94 I-100 I-106 I-110 I-159 I-165 \\
\hline Toma de tierra & I-130 I-140S I-150S \\
\hline Certificaciones & IEC 61215 y Clase II mediante certificado TÜV \\
\hline Sección de Cable & 4-10 $\mathrm{mm}^{2}$ \\
\hline Terminal de Conexión & $\begin{array}{c}\text { Bornera atornillable con posibilidad de } \\
\text { soldadura. Multicontacto opcional }\end{array}$ \\
\hline
\end{tabular}

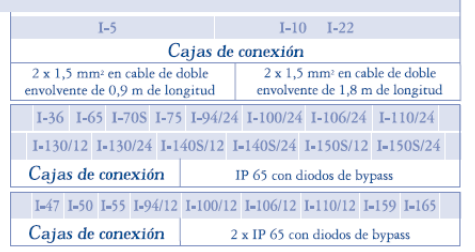




\section{APPENDIX B}

\section{Discover}

\section{Dry Cell Traction Industrial Battery Block}

Discover ${ }^{\oplus}$ Dry Cell Traction Series provide superior high integrity and reliability for commercial, industrial and private applications. The maintenance-free, thick plate construction, designed for tough applications and repeated deep discharging makes the EV Series the definitive choice for robust Traction applications including Home Medical Equipment (HME), Electric Vehicle, Automated Guided Vehicles (AGV), Aerial Lifts, Floor Cleaning Equipment, Robotics, Materials Handling, Renewable Energy and Marine / RV applications.

\section{MECHANICAL DRAWINGS}
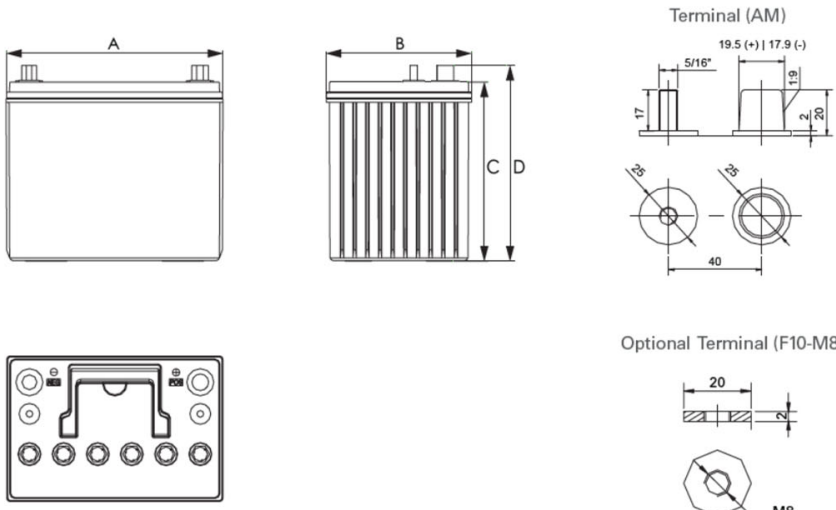

Optional Terminal (F10-M8)

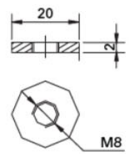

MECHANICAL SPECIFICATIONS

\begin{tabular}{|c|c|c|}
\hline Industry Reference & \multicolumn{2}{|c|}{24} \\
\hline Length (A) & 10.2 in & $258 \mathrm{~mm}$ \\
\hline Width (B) & $6.8 \mathrm{in}$ & $172 \mathrm{~mm}$ \\
\hline Height (C) & 8.4 in & $214 \mathrm{~mm}$ \\
\hline Total Height (D) & 9.3 in & $235 \mathrm{~mm}$ \\
\hline Weight & $53 \mathrm{lbs}$ & $24 \mathrm{kgs}$ \\
\hline Terminal (0pt' $)^{*}$ & \multicolumn{2}{|c|}{ AM (F10-M8) } \\
\hline Cell(s) & \multicolumn{2}{|c|}{6} \\
\hline Electrolyte & 1.2875 S.G. & AGM \\
\hline
\end{tabular}

ELECTRICAL SPECIFICATIONS

\begin{tabular}{|c|c|c|}
\hline Voltage & \multicolumn{2}{|c|}{$12 \mathrm{~V}$} \\
\hline $80 \%$ DOD Voltage Cutoff & \multicolumn{2}{|c|}{$11.4 \mathrm{~V}$} \\
\hline Internal Resistance & \multicolumn{2}{|c|}{$4.60 \mathrm{~m} \Omega$} \\
\hline Short Circuit $\left(20^{\circ} \mathrm{C} \mid 68^{\circ} \mathrm{F}\right)$ & \multicolumn{2}{|c|}{$2400 \mathrm{~A}$} \\
\hline Self Discharge & \multicolumn{2}{|c|}{ Less than $3 \%$ per month $\left(20^{\circ} \mathrm{C} \mid 68^{\circ} \mathrm{F}\right)$} \\
\hline Cranking Amps"* & $630 @ 0^{\circ} \mathrm{C}\left(32^{\circ} \mathrm{F}\right)$ & $525 @-18^{\circ} \mathrm{C}\left(0^{\circ} \mathrm{F}\right)$ \\
\hline Charge Temperature & \multicolumn{2}{|c|}{ Min: $-10^{\circ} \mathrm{C}\left(14^{\circ} \mathrm{F}\right) \mid \operatorname{Max}: 50^{\circ} \mathrm{C}\left(122^{\circ} \mathrm{F}\right)$} \\
\hline Discharge Temperature $* * \cdots$ & \multicolumn{2}{|c|}{ Min: $-40^{\circ} \mathrm{C}\left(-40^{\circ} \mathrm{F}\right) \mid \operatorname{Max}: 50^{\circ} \mathrm{C}\left(122^{\circ} \mathrm{F}\right)$} \\
\hline Storage & \multicolumn{2}{|c|}{ Min: $-20^{\circ} \mathrm{C}\left(-4^{\circ} \mathrm{F}\right) \mid \operatorname{Max}: 60^{\circ} \mathrm{C}\left(140^{\circ} \mathrm{F}\right)$} \\
\hline
\end{tabular}

ELECTRICAL SPECIFICATIONS

\begin{tabular}{|c|c|c|c|c|c|c|c|c|c|c|}
\hline \multicolumn{9}{|c|}{ Amp Hours (AH) } & \multicolumn{5}{c|}{ Minutes of Discharge } \\
\hline 100 HR & 20 HR & 10 HR & 5 HR & 3 HR & 1 HR & @25A & @56A & @75A & @85A & @100A \\
\hline 94 & 85 & 78 & 72 & 66 & 54 & 155 & 57 & 38 & 32 & 27 \\
\hline
\end{tabular}

\begin{tabular}{|c|c|c|c|c|}
\hline Maximum Current & Peak (5 seconds) & Peak (10 seconds) & Continuous & Recommended Continuous \\
\hline Charge & $1 \mathrm{C} 10 \mathrm{Hr}$ & $0.75 \mathrm{C} 10 \mathrm{Hr}$ & $0.5 \mathrm{C} 10 \mathrm{Hr}$ & $0.3 \mathrm{C} 10 \mathrm{Hr}$ \\
\hline Discharge & $2 \mathrm{C} 10 \mathrm{Hr}$ & $1.5 \mathrm{C} 10 \mathrm{Hr}$ & $1 \mathrm{C} 10 \mathrm{Hr}$ & $0.5 \mathrm{C} 10 \mathrm{Hr}$ \\
\hline
\end{tabular}

Updated: Jan. 1", 2017

44 -13511 Crestwood Place, Richmond, BC, V6V 2E9, Canada $\quad$ C + +1.778.776.3288

@ info@discoverbatterycon

\section{BENEFITS \& FEATURES}

Advanced battery designs that exceed Original Equipment Manufacturer requirements.

Enhanced alloy Traction heavy duty grids gives consistent active material adhesion and corrosion resistance for longer runtime and extended service life.

Higher density active material paste o deliver longer runtimes at high

Lower specific gravity for reduced heat and cycle life performances.

High impact reinforced copolymer and polypropylene cases with flat top designs.

Sealed Non-Spillable Maintenance-free technology.

$99.9 \%$ gas recombination reduces off gassing and water loss.

Multiple battery terminal options and carrying handles available.

Excellent for use in environmentally sensitive areas.

UL94 recognized flame arresting low pressure safety vents (UL94 V0 ratin available).

Classified as a non-spillable battery is

not restricted for transportation by:

- Air (IATAICAO provision 67)

Ground (STB, DOT-CFR-HMR49)

- Water (IMDG amendment 27)

CERTIFIED QUALITY

Discover and its facilities and products are tested and certified to multiple standards:

ISO, UL, CE, and QS standards

- ETTS Germany

- Euro Bat classification for Environmental Stewardship Standards

Designed in accordance with and published in compliance with applicable $\mathrm{BCI}, \mathrm{IEC}$ and $\mathrm{BS} \mathrm{EN}$ standards, including:

IEC60896-21/2

BS EN 60254-1:200

- AS/NZS 4029.2.2000

\section{C $\in \mathbf{N}$

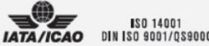

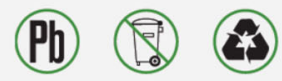




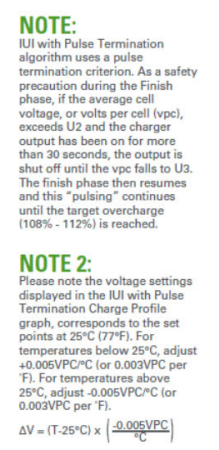

TEMPERATURE EFFECTS ON CAPACITY

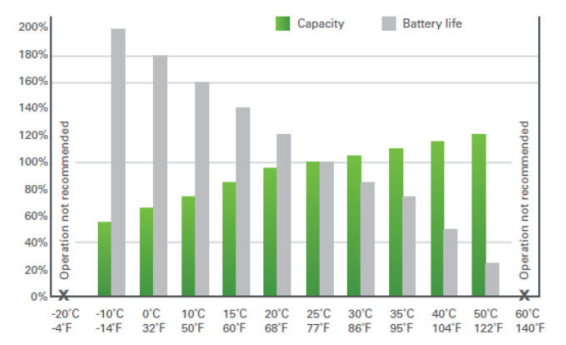

OPEN CIRCUIT VOLTAGE IN RELATION TO THE STATE OF CHARGE $\left(20^{\circ} \mathrm{C}\right)$

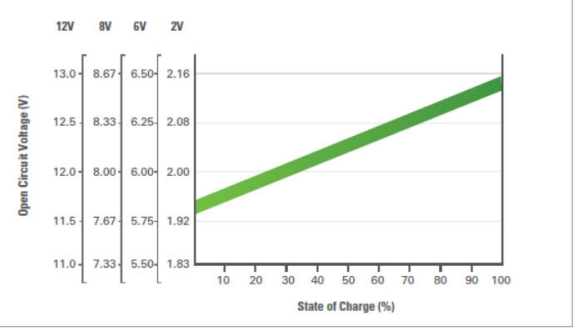

IUI WITH PULSE TERMINATION CHARGE PROFILE

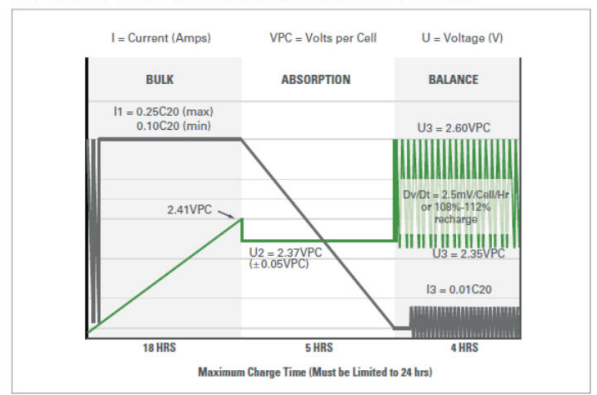

IUU CHARGE PROFILE

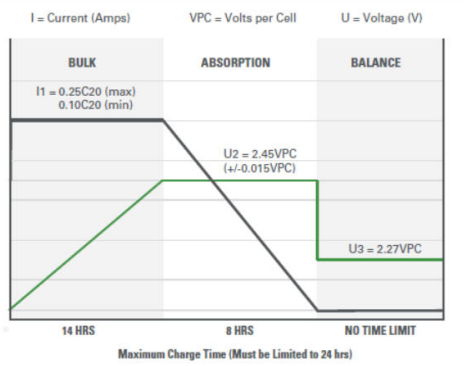

CYCLE LIFE IN RELATION TO DEPTH OF DISCHARGE $\left(25^{\circ} \mathrm{C}\right)$

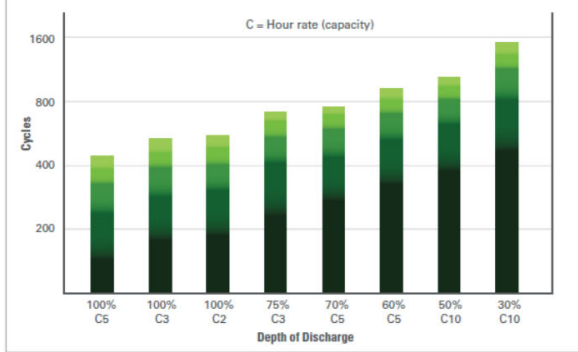

SELF-DISCHARGE CHARACTERISTICS

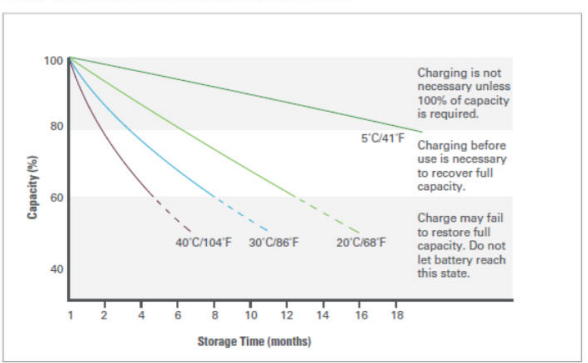

IUI CHARGE PROFILE

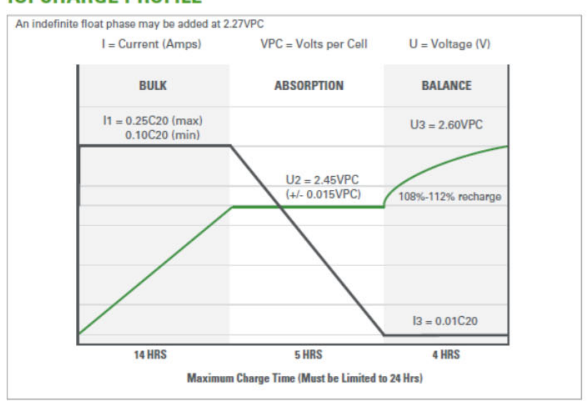

RELATION BETWEEN CHARGING, VOLTAGE AND TEMPERATURE

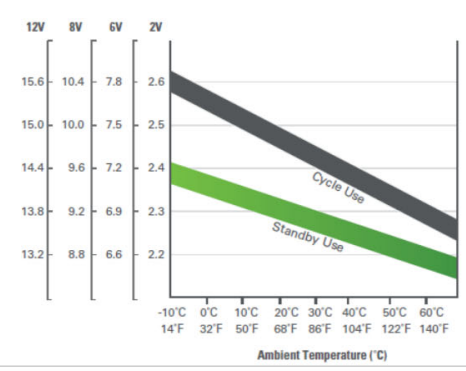




\section{APPENDIX C}

To assess the degradation of the Isofoton I-94/24 PV modules an understanding of the common pv module rating methods must be established.

STC - Standard Test Conditions

- 1000 watts $/ \mathrm{m}^{2}$ irradiance

$-25^{\circ} \mathrm{C}$ cell temperature

- 1.5 air mass

PTC - Which means Photovoltaics for Utility Systems Applications (PV USA) Test Conditions

- 1000 watts $/ \mathrm{m}^{2}$ irradiance

$-20^{\circ} \mathrm{C}$ ambient temperature

- 1.5 air mass

- $1 \mathrm{~m} / \mathrm{s}$ wind speed

Nominal Operating Cell Temperature (NOTC) - the temperature of the cells when operating at an ambient temperature of $20^{\circ} \mathrm{C}$, and air mass of 1.5 , and insolation of $0.8 \mathrm{~kW} / \mathrm{m}^{2}$ and a wind speed of $1 \mathrm{~m} / \mathrm{s}$.

$T_{c}=T_{a}+\left[\frac{N O T C-20^{0}}{0.8}\right] G$

$\mathrm{Tc}=$ the new cell temperature

$\mathrm{Ta}=$ the new ambient air temperature

$\mathrm{G}=$ the new insolation value

Calculating $I_{s c}, V_{o c}$ at a new temperature

$V_{o c}=V_{o c}\left(\right.$ at $\left.25^{\circ} \mathrm{C}\right)\left[1+\left(\mathrm{T}_{\mathrm{C}}-25^{\circ} \mathrm{C}\right)\left(\Delta \mathrm{V}_{\mathrm{oc}} / \Delta \mathrm{T}\right)\right]$

$I_{s c}=I_{s c}\left(\right.$ at $\left.25^{\circ} \mathrm{C}\right)\left[1+\left(\mathrm{T}_{\mathrm{C}}-25^{\circ} \mathrm{C}\right)\left(\Delta \mathrm{I}_{\mathrm{sc}} / \Delta \mathrm{T}\right)\right]$

Using collected data from module testing

Actual air temperature $=7.4^{\circ} \mathrm{C}$

Actual module temperature $=36.1{ }^{\circ} \mathrm{C}$

Actual $\mathrm{G}=0.866 \mathrm{~kW} / \mathrm{m}^{2}$

NOTC from Isofoton I-94/24 product specifications $=47^{\circ} \mathrm{C}$

Using equation (1) to compare and estimated cell temperature to an actually measured cell temperature using a known ambient air

$\mathrm{T}_{\mathrm{c}}=7.4^{\circ} \mathrm{C}+\{[(47-20) / 0.8] 0.866\}=36.6^{\circ} \mathrm{C}$

With an actual measure cell temperature of $36.1^{\circ} \mathrm{C}$

Using equation (2) and measured $\mathrm{V}_{\text {oc }}$ values from collected data

Typical values for $\Delta \mathrm{V}_{\mathrm{oc}} / \Delta \mathrm{T}$ for monocrystalline cells $=-0.0039$

Stated value of $V_{o c}\left(\right.$ at $\left.25^{\circ} \mathrm{C}\right)$ from Isofoton I-94/24 product specifications $=39.6$ Volts

Known measured value of the cell $=55^{\circ} \mathrm{C}$ during testing

We get a new value of $\mathrm{V}_{\text {oc }}$ at the test conditions of 33.4 Volts

This equates to a percentage difference of $4.48 \%$ from the specified new module voltage at these conditions 
Using equation (3) and measured values of $I_{s c}$ from collected data $I_{s c}=I_{s c}\left(\right.$ at $\left.25^{\circ} \mathrm{C}\right)[$

Typical values for $\Delta I_{s c} / \Delta \mathrm{T}$ for monocrystalline cells $=-0.00077$

Stated value of $V_{o c}\left(\right.$ at $\left.25^{\circ} \mathrm{C}\right)$ from Isofoton I-94/24 product specifications $=3.27 \mathrm{amps}$

Known measured value of the cell $I_{s c}$ at $55^{\circ} \mathrm{C}=2.87 \mathrm{amps}$

We get a new value of $I_{s c}$ at the test conditions of $3.346 \mathrm{amps}$

This equates to a percentage difference of $14.212 \%$ from the specified new module voltage at these conditions 